Z Badań nad Książką i Księgozbiorami Historycznymi 2021, t. 15, z. 1

Krzysztof Szelong

Książnica Cieszyńska

k.szelong@kc-cieszyn.pl

\title{
Śląski Lukullus? Baron Jan Jerzy Cygan ze Słupska na Frysztacie i Dobrosławicach w świetle zebranych przez niego książek
}

\author{
The Silesian Lucullus? Baron Jan Jerzy Cygan from Słupsk of \\ Frysztat and Dobrosławice in the light of his book collection
}

\begin{abstract}
Freiherr Johann Georg Czigan von Slupsk auf Freistadt und Dobroslawitz, who died in 1640, was the patron and friend of the Silesian poets Daniel Czepko and Wenzel Scherffer von Scherfferstein. With their poetic messages, they contributed to the dissemination of the image of the Freiherr von Slupsk as an erudite and book lover. This article attempts to verify the above opinion and identify the sources of the intellectual formation of Johann Georg Czigan and the genesis of his literary and bibliophile interests. It describes the environmental connections of Johann Georg Czigan and the ties that connected him with the world of nobilitas literaria. It presents books that were his property and have survived to this day, adorned with the baron's supralibros, one of the two currently known aristocratic proprietary marks of this kind from the Duchy of Cieszyn.
\end{abstract}

Key words: Freiherr Johann Georg Czigan von Slupsk auf Freistadt und Dobroslawitz, Upper Silesia, Duchy of Teschen, nobility, Grand Tour, nobilitas literaria, aristocratic libraries, supralibros

Słowa kluczowe: baron Jan Jerzy Cygan ze Słupska na Frysztacie i Dobrosławicach (Freiherr Johann Georg Czigan von Slupsk auf Freistadt und Dobroslawitz), Górny Śląsk, księstwo cieszyńskie, szlachta, Grand Tour, nobilitas literaria, biblioteki szlacheckie, superekslibris 
W 1991 r. w trakcie skontrum biblioteki Leopolda Jana Szersznika, które związane było z dokonującym się wówczas przejęciem zbiorów dawnego Oddziału Zabytkowego Biblioteki Śląskiej przez Miejską Bibliotekę Publiczną w Cieszynie, autor niniejszego artykułu odkrył książkę ozdobioną nieznanym dotąd superekslibrisem barona Jana Jerzego Cygana ze Słupska na Frysztacie i Dobrosławicach. W tym samym roku Oddział Zabytkowy odwiedziła Profesor Barbara Bieńkowska, ówczesna prezes Polskiego Towarzystwa Bibliologicznego, której wizyta i poczynione w jej trakcie ustalenia dały początek zaangażowaniu się czołowych polskich bibliologów i bibliotekoznawców na rzecz ratowania cieszyńskiego dziedzictwa piśmienniczego. Podjęte wówczas działania programowe i organizacyjne, przebiegające pod czujnym okiem prof. Bieńkowskiej, już 1 I 1994 r. zaowocowały przekształceniem Oddziału Zabytkowego MBP w Cieszynie w samodzielną Książnicę Cieszyńską, studyjną bibliotekę zabytkową, której powierzono pieczę nad całością zadań związanych z ochroną, konserwacją, opracowaniem i udostępnieniem cieszyńskich księgozbiorów zabytkowych. Dzisiaj, gdy Książnica Cieszyńska ma już za sobą jubileusz ćwierćwiecza działalności, niechaj ten artykuł, do którego powstania asumpt dała książka odnaleziona przed 30 laty, w czasie, gdy prof. Bieńkowska po raz pierwszy wizytowała cieszyńskie biblioteki zabytkowe, będzie skromnym dowodem pamięci, wdzięczności i czci, jakimi współtwórczyni i pierwsza Prezes Polskiego Towarzystwa Bibliologicznego darzona jest w Cieszynie. Serdeczne wyrazy wdzięczności autor kieruje także pod adresem Hanny Łaskarzewskiej, która jako sekretarz PTB towarzyszyła w 1991 r. Profesor Barbarze Bieńkowskiej podczas jej wizyty w Cieszynie i od tego czasu nieprzerwanie wspiera wszelkie działania na rzecz cieszyńskich księgozbiorów zabytkowych, pracując m.in. w Radzie Programowej Oddziału Zabytkowego MBP, a następnie - aż do dzisiaj - także w Radzie Programowej Książnicy Cieszyńskiej.

Dnia 16 I 1640 r. w położonym nieopodal Koźla majątku Zakrzów zmarł górnośląski arystokrata baron Jan Jerzy Cygan ze Słupska, niegdysiejszy współwłaściciel znajdującego się na terenie księstwa cieszyńskiego państwa stanowego niższego rzędu (status minor) we Frysztacie (obecnie część Karwiny na Zaolziu) oraz dóbr Dobrosławice w księstwie opawskim (obecnie Republika Czeska) ${ }^{1}$. Na pobyt w Zakrzowie, który w tym czasie był własnością

1 Data na podstawie: D. Czepko, Auff Deß Wolgebohrnen Herren Herren Hans Georg Czigan/Freyherrn von Schlupska/ Herrn auff Freystadt/Dobroslawitz und Sacraco/ in Gott seeligen Abschied : So geschehen den 16. Jenner deß 1640. Jahres, Breßlaw 1640 oraz W. Scherffer, Leichgesänge und Grabschrifften, Brig 1646, s. 45; w późniejszej literaturze śmierć J.J. Cygana często i najpewniej błędnie datowana jest na 6 I 1640 r., por.: J. Sinapius, Des schlesischen Adels anderer 
żony pana ze Słupska, Marianny z Kochcickich, stanowiąc zapewne jej wdowią oprawę pozostawioną przez pierwszego męża Wacława Szeligę ${ }^{2}$, J.J. Cygan był skazany, ponieważ frysztacka część rodowego majątku Cyganów już wówczas znajdowała się w obcych rękach, przejęta za długi, a w Dobrosławicach, mocno podupadłych i także obciążonych kredytami, gospodarował ostatni pozostały przy życiu brat Jana Jerzego, Wacław Fryderyk (zm. w 1654 r.) oraz - prawdopodobnie - siostry: Barbara Dorota (zm. w 1650 r.) i Salomea Sydonia (zm. po 1656 r.) $)^{3}$. Zdaje się też, że materialna mizeria, w jakiej znajdowała się rodzina pana ze Słupska, obok wyznawanego przez zmarłego protestantyzmu, sprawiły, że jego doczesne szczątki nie doczekały się godnego pochówku ani w rodowej kaplicy Cyganów we Frysztacie ${ }^{4}$, ani w innych kościołach zlokalizowanych na terenie dóbr należących do panów ze Słupska lub rodu Kochcickich, ale złożone zostały w... ogrodzie ${ }^{5}$. W tak symboliczny niemal sposób dobiegały

Theil, oder Fortsetzung Schlesischer Curiositäten: darinnen die gräflichen, freyherrlichen und adelischen Geschlechter so wohl Schlesischer Extraction, als auch die aus andern Königreichen und Ländern in Schlesien kommen, und entweder darinnen noch floriren ..., Leipzig und Breßlau 1728, s. 498; J. Zukal, Paméti opavské, Opava 1912, s. 221-223; L. Igálffy-Igály, Die Kiczka-Karwinsky. Eine Studie über die Herkunft der Freiherrn Karwinsky von Karwin und Czigan von Slupsk und aller anderen Familien desselben Wappen (maszynopis powielony), Wien 1969, s. 44.

2 Wskazywać na to zdaje się fakt, iż w tytule epitalamium wydanego z okazji ślubu Marianny z Kochcickich z Wacławem Szeligą ten ostatni wymieniany jest m.in. na Zakrzowie, por.: T. Aleuthner, Melos Epithalamium. Nuptiarum festivitati, Quam Generis Antiqui, Virtutis variae ... Vir Nobilissimus Et Magnificus. Dn. Wenceslaus Scheliha De Rzuchaw, In Wahnowitz/Sawerwitz/Sackraw/ \& Huhndorff/ \&c. Sponsus, Cum Natalium ... Feminarum ornamentis illustribus conspicua adolescentula Heroina Dn: Marianna Kochticia, Illustris Ac Generosi Domini, Dn: Andrea Kochtizky ... Filia Charis: Sponsa : Coselae Silesior. Ad 8. Eid. Quinctil. ... 1624. Solemn. instituebat Adcantatum nuncupatum, Nissae 1624.

3 Zemský archiv v Opavě (dalej: ZAO), zespół: Josef Zukal (dalej: Zukal), sygn. 196, k. 63-66; J. Zukal, Paměti opavské..., s. 221-227; L. Igálffy-Igály, Die Kiczka-Karwinsky..., s. 47.

4 W. Iwanek, Renesansowa plastyka nagrobna na Ślasku Cieszyńskim, „Cieszyński Rocznik Muzealny”, 1972, t. 3, s. 71; K. Müller, Heraldické památky Těšinska, Český Těšín 2012, Studie o Těšínsku, 20, s. 54-55.

5 Daniel Czepko, zwracając się do wdowy, napisał:

O Maria, die du deinem Gemahl ein ansehnliches Grabmal aus Kalk und gebrannten Steinen errichtest und ihm einen Garten bei dieser Ruhestätte weihst:

Warum quält es dich, daß die Priester der Andersgläubigen den frommen Manen - gegen das Recht der Völker - die Kirche zu verweigern wagen und die Gebeine deines geliebten Czigan bis zur Auferweckung in diesem Garten schlafen?

Maria, die Mutter unseres einzigen Erlösers, hat es ertragen, daß selbst der Erlöser dergestalt ruhen mußte. Wo immer auch dein Czigan ruht: da ist eine Kirche!

D. Czepko, Sämtliche Werke, hrsg. H.-G. Roloff u. M. Szyrocki, Bd. 2: Vermischte Gedichte, T. 1: Lateinische Gedichte, bearb. v. L. Mündt u. U. Seelbach, Berlin u. New York 1996, s. 81; por. też: Tenże, Sämtliche Werke, Bd. 3: Epische und dramatische Dichtung, Berlin u. New York 1988, s. 43; również W. Scherffer w swoim epitafium wspomniał o ogrodzie jako miejscu złożenia doczesnych szczątków J.J. Cygana: W. Scherffer, Leichgesänge und Grabschrifften ..., s. 57; znamienne, że kilka lat wcześniej godnego pochówku odmówiono także teściowi pana ze Słupska, zmarłemu jako zdrajca stanu Andrzejowi Kochcickiemu, którego ciało złożone zostało w krypcie kościoła p.w. św. Zygmunta w Koźlu dopiero po 1740 r. na mocy rozporządzeń pruskich władz, por.: L. Igálffy-Igály, 
kresu dzieje starego górnośląskiego rodu, który, osiągnąwszy na przełomie XVI i XVII w. największy w swojej historii materialny rozkwit i społeczny awans, ledwie kilka dekad później, wraz ze śmiercią Jana Jerzego i jego bezżennych braci, Karola Henryka (zm. w 1636 r.) i Wacława Fryderyka, miał ostatecznie wygasnąć.

Niejako na przekór nikczemności miejsca, w którym na wieki spocząć przyszło J.J. Cyganowi, jego śmierć wywołać musiała na Śląsku spore poruszenie. Świadectwem tego są poetyckie epitafia upamiętniające pana ze Słupska ${ }^{6}$. Wyszły one spod piór znakomitych śląskich poetów, którzy swego czasu korzystali z gościny i opieki J.J. Cygana i jego braci. Mowa tu o długo niedocenianym, a niezwykle płodnym twórcy Wacławie Scherfferze von Scherfferstein oraz Danielu Czepce, jednym z najwybitniejszych poetów niemieckiego baroku.

Epitafium D. Czepki, napisane w sierpniu 1640 r., zostało jeszcze w tym samym roku ogłoszone drukiem jako samoistna publikacja ${ }^{7}$, z kolei utwór W. Scherffera, powstały w październiku 1640 r. i zadedykowany wdowie Mariannie z Kochcickich, ukazał się w wydanym w 1646 r. w Brzegu zbiorze Leichgesänge und Grabschrifften ${ }^{8}$. W obu epitafiach znaleźć można nadzwyczaj zgodne wyrazy podziwu dla jego oddania sprawom ducha oraz erudycji.

Die Freiherren Kochticky von Kochtitz und Lublinitz, „«Adler» Zeitschrift für Genealogie und Heraldik“, 1979/1981, s. 137; A. Weltzel, Geschichte der Stadt und Festung Cosel, Cosel 1866, s. 186-187, 195; Tenże, Die Landesbeamten der Fürstenthümer Oppeln-Ratibor von 1532-1741, „Zeitschrift des Vereins für Geschichte und Alterthum Schlesien“, 1874, s. 26.

6 Drukowanymi kazaniami pogrzebowymi już w 1606 r. uczczony został najstarszy spośród braci Cyganów, który zmarł w tym roku, jeszcze jako uczeń książęcego gimnazjum w Brzegu: N. Anther, G. Heerman, Zwo Christliche Leich Predigten Uber dem Seeligen Abschiede Weyland Des Wolgebornen Jüngen Herrens/ Herrn Christoff Czigans Von Slußka auff Freystadt/ u. Welcher am II Octob. An. 1606. zum Brieg auß der Fürstlichen irdischen/ in die Himlische Schule versetzet und 2. Novembr. Anni ejusdem hernach zur Freystadt inn grosser Anschnlicher versammlung der Betrübten Blutsfreundschafft/ und anderer rittermessigen Personen inn seine Erbgrufft ist gesamlet worden. Die Erste. Bey Abführung seines verblichenen Cörpers auß der Füstl: Stadt Brieg/ nach der Freystadt seiner Sepultur/ gehalten zum Brieg 22 Octob. vorm Oppelischen Thore Durch Nicolaum Antherum Fürstlichen Briegischen Hoffprediger/ und gemeltes Fürstenthumbs General Superintendenten. Die Andere. Bey der Volckreichen bestattung und beysetzung den 2. Novemb. in der Pfarkirchen zur Freystadt/ Gethan durch Georgium Heerman. B S. Pastorem und Inspectorem der Kirchen und schulen daselbst, [Brzeg 1606?]; także po śmierci Barbary Doroty Cyganówny ukazało się drukowane epitafium pochodzące spod pióra zaprzyjaźnionego z Danielem Czepką Friedricha Fischera: F. Fischer, In obitum Illustris Heroinae Barbarae Dorotheae Cziganianae, natae L. Baronissae de Stupska, Freistadt et Dobroslawiz, Quae A. C. M DC L. Mens. Septemb. d. 27. Fatali peractae Mortalitatis termino, Terrae magnae nimirum Marti, Exuvias; Deo autem Spiritum, reddens, pie, placide, ac beate Dobroslawicii obdormivit, [Wrocław 1650], 4 k., por.: U. Seelbach, Die Ermittlung personenbezogener Informationen für den Kommentar der Czepko-Ausgabe, [w:] Kommentierungsverfahren und Kommentarformen. Hamburger Kolloquium der Arbeitsgemeinschaft für germanistische Edition, 4. bis 7. März 1992, autor- und problembezogene Referate, hrsg. G. Martens, Tübingen 1993, s. 226.

7 D. Czepko, Auff Deß Wolgebohrnen Herren ..., 4 k.

8 W. Scherffer, Leichgesänge und Grabschrifften..., s. 45-65. 
Także biogram J.J. Cygana, opracowany przez znakomitego śląskiego jurystę i dziejopisa Mikołaja Henela, a umieszczony w monumentalnym, a nadal jeszcze pozostającym w rękopisie dziele biograficznym Silesia Togata ${ }^{9}$, na plan pierwszy wysuwa głęboką wiedzę pana Frysztatu i uznanie, jakim cieszył się wśród europejskich uczonych. Opinie sformułowane przez D. Czepkę i W. Scherffera, podobnie jak wypełniony komplementami biogram pana ze Słupska opracowany przez M. Henela, a upowszechniony dzięki edycji zamieszczonej w wydanym przez Michała Józefa Fibigera zbiorze Silesiographia renovata ${ }^{10}$, były - widać - na tyle przekonujące, że we wszystkich późniejszych herbarzach i leksykonach, w których znalazło się miejsce dla wzmianek o J.J. Cyganie, są one zredukowane do informacji o jego erudycji i związkach ze światem uczonych ${ }^{11}$.

Że nie były to jednak tylko konwencjonalne pochwały, dowodzi biografia Jana Jerzego, który, przyszedłszy na świat w ostatnich latach XVI w., już w pierwszej dekadzie XVII w. trafił do książęcego gimnazjum akademickiego w Brzegu, gdzie wkrótce dołączyli do niego jego młodsi bracia ${ }^{12}$. Ich edukacja na średnim szczeblu objęła jeszcze prawdopodobnie pobyt w Świdnicy i naukę w tamtejszej szkole łacińskiej, która, choć wówczas nie osiągnęła jeszcze stopnia gimnazjalnego, cieszyła się wysoką renomą ${ }^{13}$. W 1611 r. bracia Cyganowie

9 M. Henel, Silesia Togata (rkps.), Biblioteka Uniwersytecka we Wrocławiu, sygn. R 570 (mf 8385), cap. LI, s. 207-208.

10 Tenże, Silesiographiae Henelianae renovatae pars altera [Cap. VIII., De statu hominum sive Generibus et ordinibus, quibus Silesiarum incolae inter se distincti], Wratislaviae et Lipsiae 1704, s. 491-493.

11 J. Sinapius: Des schlesischen Adels anderer Theil..., s. 498; J.F. Gauhe, Des Heil. Röm. Reichs Genealogisch-Historisches Adels-Lexicon, Darinnen die älteste und ansehnlichste adeliche, freyherrliche und gräfliche Familien nach ihrem Alterthum, Ursprunge, Vertheilungen in unterschiedene Häuser [et]c. nebst den Leben derer daraus entsprossenen berühmtesten Personen, insonderheit Staats-Minister ... mit bewährten Zeugnissen vorgestellet werden ..., Leipzig 1740, szp. 384; K.F. Schönwälder, Geschichtliche Ortsnachrichten von Brieg und seinen Umgebungen. Einleitung. Vorstädte. Umgebung, T. 2, Brieg 1846, s. 502; M. Kolář, Cikánové ze Slupska, [w:] Ottův slovník naučný, D. 5, Praha 1892, s. 367; V. Prasek, Slavní někteři mužové z Těšinska, „Kalendář slezský“, 6, 1902, s. 53; J. Pilnáček, Rody starého Slezska, Vyd. 2, Brno 1991-1998, s. 1131; Johann Georg Czigan (Freiherr), Wikipedia, [online] https://de.wikipedia.org/wiki/Johann_Georg_Czigan_(Freiherr)\#cite_ref-5, [dostęp 02.02.2021].

12 J.G. Weinschenk, Historische Nachricht von der Stiftung und den Schicksalen des königlichen Gymnasii Illustris zu Brieg wie auch von dessen Rectoribus und Professoribus, bey den Andenken der vor zweyhundert Jahren geschehenen Grundlegung desselben abgefasset..., Brieg 1764, s. 30; K.F. Schönwälder, J.J. Guttmann, Geschichte des Königlichen Gymnasiums zu Brieg, Breslau 1869, s. 89; L. Igálffy-Igály, Die Freiherren Kochticky..., s. 139; M. Holý, Zrození renesančního kavalíra. Výchova a vzdèlávání šlechty z českých zemí na prahu novověku (1500-1620), Praha 2010, s. 228.

13 Śladem obecności w Świdnicy braci Cyganów, w tym również Jana Jerzego są epigramaty ich autorstwa adresowane do zawierającego małżeństwo preceptora Johanna Hartmanna, konrektora świdnickiej szkoły łacińskiej, zamieszczone w zbiorze: Nuptiis viri clarissimi et doctissimi ... M. Joannis Hartmanni, Gymnasii Svidniciensis Con-Rectoris ... sponsi et ... Susannae Langiae ... Wol- 
zostali osieroceni przez ojca, a opiekę nad nimi powierzono kilku górnośląskim arystokratom, w tym także panu Lublińca baronowi Janowi (III) Kochcickiemu z Kochcic ${ }^{14}$, który - jak chcą niektórzy genealodzy - poślubił także ich matkę, Mariannę z Rederów z Redern ${ }^{15}$. Kiedy Jan (III) Kochcicki kilka lat później zmarł, Jan Jerzy trafił prawdopodobnie pod opiekę jego młodszego brata, Andrzeja Kochcickiego z Kochcic na Koszęcinie. W ten sposób młody cieszyński szlachcic znalazł się w środowisku duchownych, nauczycieli i literatów sławiących koszęcińskiego „patrona muz”, który to tytuł na trwałe związać miał się $z$ imieniem A. Kochcickiego seniora ${ }^{16}$.

W Polsce znany jest on przede wszystkim jako opiekun śląskiego kuźnika-literata Walentego Roździeńskiego i adresat jego dedykacji w Officina ferraria, a także patron ariańskiego poety Szymona Pistoriusa. Lista pisarzy i uczonych, którzy w różnym czasie zdecydowali się ofiarować panu Koszęcina swoje utwory jest jednak znacznie dłuższa i obejmuje nie tylko lokalnych twórców, których bezpośrednie kontakty z A. Kochcickim można z łatwością wyjaśnić, ale także autorów związanych ze środowiskami uniwersyteckimi, cieszących się sławą i uznaniem w całej Europie. Jak można sądzić, nie był to tylko efekt rosnącego szacunku, jaki górnośląski arystokrata w sposób naturalny zyskiwał sobie w świecie nobilitatis literariae, ale przede wszystkim rezultat jego świadomych zabiegów. Liczne grono sławiących go poetów i pisarzy przysparzało mu bowiem nie tylko splendoru, ale budowało pozycję rodu, stanowiąc $\mathrm{w}$ arystokratycznym świecie ważny element reprezentacji ${ }^{17}$.

Jeszcze w tym samym 1614 r. J.J. Cygan wraz z Andrzejem juniorem oraz Joachimem, synami - odpowiednio - Jana (III) i Andrzeja Kochcickich, a także ich powinowatym baronem Janem Bernardem (II) Maltzanem wyruszyli w swoją Grand Tour. Ich wyjazd poprzedziła zorganizowana 7 X 1614 r. w koszęcińskim dworze uroczystość pożegnalna, w trakcie której młodzi Kochciccy oraz J.B. Maltzan mieli okazję zaprezentować przygotowane przez siebie i już chyba wcześniej wydane drukiem okolicznościowe utwory, popisując się

fgangi Langii ... filiae ... ad diem 26. Augusti Anno 1613. celebrandis, Lignici [post 26 VIII 1613], k. A2; w tym czasie do renomowanej świdnickiej szkoły uczęszczał także Daniel Czepko, W. Milch, Daniel Czepko. Persönlichkeit und Leistung, Breslau 1934, Einzelschriften zur Schlesischen Geschichte, Bd. 12, s. 6-7.

14 ZAO, zespół: Slezský stavovský archiv (dalej: AS), inv. č. 860, f. 15.

15 L. Igálffy-Igály, Die Freiherren Kochticky ..., s. 136, przyp. 77.

16 Już w 1595 r. tytułem ,wielkiego patrona muz” obdarzył pana z Kochcic Szymon Pistorius, por.: M. Pawłowiczowa, Szymon Pistorius w kręgu Andrzeja Kochcickiego, [w:] Prace Historycznoliterackie, 12: Studia Staropolskie, pod red. J. Zaremby, Katowice 1979, s. 84.

17 Szerzej na temat A. Kochcickiego i jego aktywności kulturalnej zob.: K. Szelong, Andreas Kochtitzki d.̈̈. - Mäzen, Politiker, Soldat, [w:] Adel in Schlesien, Bd. 1: Herrschaft-Kultur-Selbstdarstellung, hrsg. J. Harasimowicz u. M. Weber, München 2010, s. 363-392; tam również dalsza literatura. 
zdobytymi dotychczas umiejętnościami retorycznymi i poetyckimi ${ }^{18}$. Wszystkim peregrynantom, w tym również J.J. Cyganowi oraz towarzyszącemu im preceptorowi J. Bruckowi Angermundtowi, swój drukowany utwór poetycki ofiarował z kolei koszęciński pastor Daniel Murovius, który już w tytule zapowiedział, że wyruszający w drogę młodzi śląscy arystokraci zamierzają studiować w Strasburgu oraz zwiedzić Francję i Italię ${ }^{19}$. Nie był to wprawdzie pierwszy druk, w którym pojawiło się nazwisko J.J. Cygana ${ }^{20}$, otworzył on natomiast długą listę publikacji, które ich autorzy zdecydowali się frysztackiemu baronowi ofiarować. Najwięcej powstało ich oczywiście w czasie trwających aż do 1625 r. akademickich peregrynacji ${ }^{21}$.

Zgodnie z pierwotnymi planami zaprowadziły one J.J. Cygana najpierw do Strasburga, gdzie pojawić się miał już 7 XI 1614 r. ${ }^{22}$, a więc równo miesiąc po koszęcińskiej uroczystości i gdzie przez ponad trzy lata pobierał naukę w tamtejszej, najsłynniejszej bodaj w Europie Akademii, a następnie po kilku latach spędzonych na Śląsku udał się do Niderlandów, wstępując na Uniwersytet w Lejdzie, na którym immatrykulował się 6 V 1622 r. ${ }^{23}$ Podczas studiów w Strasburgu towarzyszyli mu Andrzej i Joachim Kochciccy oraz J.B. Maltzan,

18 Orationes duae, qvarum prior de literarum encomio illarum utilitate et praestantia a Johanne Bernhardo Malczan L.B. a Wartenberg et Penczelin in Milicz etc., altera metricis pedibus contexta ab Andrea Kochticzki, L.B. a Kochticz et Lublenietz in Kossenczin et Turnawa, annum aetatis 15 agente in arce Kossentina cum Musis ibi valedicerent 7 id. Octob: hora 9. matut: an 1614 habitae Illustribus, Magnificis, ac Generosis, Prudentia Ac Pietate praestantibus Dominis, Dn: Joachimo Malczan L.B. a Wartenberg ... et Dn. Andreae Kochticzki L.B. a Kochticz et Lubleniecz ... dominis parentibus debitae observantiae et gratitudinis ergo dicatae, Breslae 1614.

19 D. Murovius, Bivium Herculis ad Ilustres et Generosos L.B. Jan Bernhardum Malczan L.B. a Wartemberg et Penczelin in Milicz ..., Dn. Jan Georgium Czigan L.B. a Slupska in Freistad et Drobroslawicz ..., Joachimum Kochticzki L.B. a et in Kochticz et Lubleniecz ..., Andream Kochticzki, L.B. a Kochticze et Lubleniecz in Kossentin et Turnawa ... studiorum gratia Argentoratum profecturos, deinde Galliam et Italiam perlustraturos ephoro nobili et cl. viro Dn. Jacobo a Bruck cogn. Angermund, Breslae 1614.

20 Poza wspomnianym już wierszykiem, którym J.J. Cygan uczcił swego świdnickiego preceptora (por. przyp. 13) epigramat jego autorstwa zamieszczony został także w zbiorku zawierającym gratulacje przygotowane przez kilku baronowskich synów (w tym wszystkich trzech braci Cyganów) pobierających naukę w książęcym gimnazjum w Brzegu dla rektora tegoż gimnazjum Jakuba Schickfussa z okazji uzyskania przez niego tytułu doktorskiego: Ara honoris viro nobilissimo et eminentissimo Jacobo Schickfusio Svebvsiensi Silesio, novo juris utriusq; doctori, Gymnasii Bregensis Rectori, Institutionum Imperial. Professori, bene merito Praeceptor posita a Baronibus illustre Bregeum frequwntantibus V. Novembr. Stilo. N. Anno M.DC.XII., Bregae 1612, k. A2.

21 Na temat przebiegu Grand Tour braci Cyganów szerzej zob.: K. Szelong, Podróże edukacyjne szlachty cieszyńskiej (do końca XVII wieku), [w:] Książka - biblioteka - szkoła w kulturze Ślaska Cieszyńskiego. Materiaty z konferencji naukowej Cieszyn 4-5 listopada 1999, pod red. J. Spyry, Cieszyn 2001, s. 85-94.

22 Tacyt, C. Cornelii Taciti De Vita Julii Agricolae Liber, exp. a M. Berneggero, Argentorati $1617, \mathrm{k} . \mathrm{S} 2$.

23 Album Studiosorum Academiae Lugduno Batavae MDLXXV-MDCCCLXXV accedunt nomina curatorum et professorum per aedem secula, ed. W.N. Du Rieu, Hagae Comitum 1875, sp. 160. 
a w Lejdzie krąg śląskich arystokratów poszerzył się jeszcze o młodszych braci Jana Jerzego, czyli Wacława Fryderyka i Karola Henryka Cyganów, którzy postępując według inaczej wytyczonej marszruty - w 1617 r. zapisali się na Akademię w Altdorfie ${ }^{24}$, rok później na Akademię Rycerską w Tybindze ${ }^{25}$, by już w 1619 r. immatrykulować się w Lejdzie ${ }^{26}$. Choć nie dysponujemy tymczasem potwierdzeniem, iż Jan Jerzy lub towarzyszący mu Ślązacy zrealizowali zamysł poznania Francji i Włoch, z całą pewnością stwierdzić można, że rzetelnie przechodzili wszystkie przypisane swojemu stanowi etapy edukacji, poczynając od regionalnych szkół łacińskich i gimnazjów na Śląsku, przez Akademie w Strasburgu, Altdorfie i Tybindze, aż po Uniwersytet w Lejdzie $\mathrm{i}$, co godne podkreślenia, każda z wybranych przez nich szkół cieszyła się w owym czasie wysoką renomą.

Il. 1. Emblemat poświęcony J.J. Cyganowi w: J. Bruck Angermundt, Emblemata Politica. Quibus ea, quae ad principatum spectant, breviter demonstrantur, singuloru[m] vero explicatio fusius proponitur, Argentine et Coloniae 1618. Źródło: Książnica Cieszyńska,

sygn. SZ 3 P IV 38, Zdjęcie: Anna Fedrizzi-Szostok

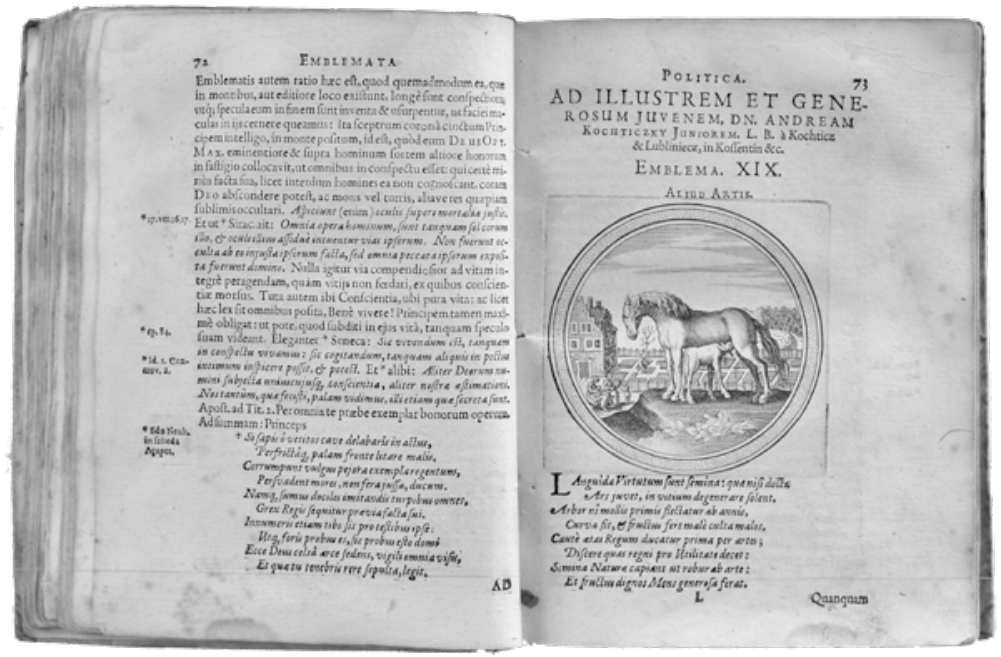

Pojawienie się podróżujących wspólnie górnośląskich arystokratów nie mogło też pozostać niezauważone na żadnej z uczelni, na której się immatrykulowali. Obecność całej grupy młodych, utytułowanych szlachciców w oczywisty sposób przydawała bowiem prestiżu każdej z placówek, zwiększając jej

24 Die Matrikel der Universität Altdorf, hrsg. E. v. Steimeyer, Bd. 2, Würzburg 1912, s. 641.

25 J. Ramsler, Blumen des fürstlichen Collegii zu Tübingen : das ist ... Verzeichnus aller ... Personen, die in diesem Collegio geflanzet ... durch angeborne Wappen unterschieden werden, Tubinga 1627, tabl. 17.

26 Album Studiosorum Academiae Lugduno Batavae..., s. 139. 
atrakcyjność w oczach innych potencjalnych studentów o arystokratycznym rodowodzie i - co nie bez znaczenia - dawała nadzieję na to, że, chcąc zadbać o właściwą dla swego stanu reprezentację, pozostawią oni w miejscu pobytu pokaźną gotowiznę. Oczekiwania te były zresztą w tym przypadku nadzwyczaj zbieżne z intencjami, jakie przyświecały śląskim studentom i ich opiekunom, przynajmniej zaś A. Kochcickiemu seniorowi, który chyba zupełnie świadomie realizację odnoszącego się do swoich podopiecznych programu edukacyjnego połączył z intensyfikacją działalności mecenasowskiej ${ }^{27}$.

Najdobitniej dowodzi tego fakt, iż ustanowiony przez niego preceptor całej grupy J. Bruck Angermundt, jurysta i zdolny literat, mający także bogate doświadczenia w roli efora szlacheckiej, głównie polskiej młodzieży, wiózł w swoim bagażu autograf okazałego anagramatyczno-emblematycznego dzieła poświęconego A. Kochcickiemu, które, choć napisane już w 1612 r., drukiem ukazało się dopiero w Strasburgu, kilka miesięcy po tym, gdy pojawili się tam śląscy arystokraci ${ }^{28}$. Tom poprzedzony został wierszykami ofiarowanymi autorowi przez wszystkich jego podopiecznych. Napisany przez J.J. Cygana epigramat dotyczył - a jakże! - sławy ${ }^{29}$. Odtąd młody cieszyński arystokrata miał się pojawiać, bądź jako adresat dedykacji, bądź jeden z autorów włączonych do danego druku wierszyków pochwalnych, w niemal wszystkich wydanych w Strasburgu dziełach J. Brucka Angermundta, których w sumie, wliczając $\mathrm{w}$ to wznowienia oraz wersje francuskojęzyczne, pomiędzy 1615 a $1618 \mathrm{r}$. ukazało się tam aż sześć, a wśród nich trzy efektowne druki emblematyczne, które tak autorowi, jak i jego patronom zapewniały europejski rozgłos ${ }^{30}$.

27 Por.: K. Szelong, Andreas Kochtitzki..., s. 370-375.

28 Tamże, s. 371; M. Schilling, Jakob von Bruck-Angermundt und seine Emblembücher, [w:] Die oberschlesische Literaturlandschaft im 17. Jahrhundert, hrsg. G. Kosselek, Bielefeld 2001, s. 141; por. też: E. Haertel, Der Kochtizkykreis. Ein Kulturbild aus Oberschlesien vom Beginn des 17. Jahrhunderts, „Schlesische Geschichtsblätter”, 1941, 3/4, s. 75; Taż, Andreas Freiherr von Kochtitzky ein Mäzen Oberschlesiens um die Zeit des Dreißigjährigen Krieges, T. 1, „Der Oberschlesier", 1936, H. 9, s. 493; Taż, Jacob von Bruck-Angermundt, ein vergessener Dichter und großer Patriot Schlesiens, „Zeitschrift des Vereins für Geschichte Schlesiens”, 1941, s. 132; P. Oszczanowski, Przygoda pewnych emblematów, czyli rzecz o destrukcji wzorca, „Dzieła i Interpretacje”, 1996, s. 175.

29 J. Bruck Angermundt, Decades duae anagrammatum et emblematum ex nomine Illustris, Generosi, et Magnifici Domini, D. Andeae Kochticzky, Argentorati 1615, k. A2.

30 Nazwisko pana ze Słupska bądź to w roli adresata dedykacji, bądź autora wierszyków dedykowanych autorowi znaleźć można w: J. Bruck Angermundt, Decades duae anagrammatum et emblematum, k. A2; Tenże, Emblemata Moralia \& Bellica (Les Emblemes Moraulx Et Militaires), Argentorati 1615-1616, bp; Tenże, Princeps Plinianus. Sive Aphorismi Politici ex C. Plini Secundi Panegyrico Ad Traianum Tetrastichis redditi. Quibus Breves Dissertationes accesserunt, Argentinae 1616, k. A4 (nast. wyd. 1617); Tenże, Emblemata Politica. Quibus ea, quae ad principatum spectant, breviter demonstrantur, singuloru[m] vero explicatio fusius proponitur, Argentine et Coloniae 1618, k. A4 i K3; por.: M. Schilling: Handschrift und Druck, Anagramm und Emblem. Ein unbekanntes Emblembuch des Jakob von Bruck-Angermundt mit Stichen von Matthaeus Merian, [w:] Polyvalenz und Multifunktionalität der Emblematik, T. 2 (Mikrokosmos. Beiträge zur Literaturwissenschaft und 
Obecność w kręgu koszęcińskiego „patrona muz” sprawiała, że na młodego J.J. Cygana spływała część splendoru, jaki otaczał członków rodu Kochcickich i gwarantowała, że twórcy pragnący oddać hołd właścicielowi Koszęcina swoje utwory niemal automatycznie ofiarowywali także panu ze Słupska. Bez wątpienia też aspiracje przejawiane przez Kochcickich oraz ich mecenasowska aktywność stanowić musiały dla J.J. Cygana wzorzec i inspirację do poszukiwania sławy w analogiczny dla nich sposób. Wszystko to razem zaowocowało wieloma publikacjami, które ukazały się w latach studiów braci ze Słupska, a w których pojawiają się oni bądź jako adresaci, bądź przynajmniej jako autorzy drobnych utworów ofiarowywanych autorowi danej publikacji. Mowa tu nie tylko o drukach akademickich, dysputacjach, w których młodzi Ślązacy brali udział, czy też wydawnictwach okolicznościowych pochodzących spod piór starszych kolegów oraz początkujących adeptów nauki, ale także o dziełach ich sławnych nauczycieli oraz literatów niezwiązanych w sposób formalny z uczelniami, na których śląscy arystokraci pobierali nauki, jak np. Johanna Othonia w Strasburgu czy Caspar Barlaeus w Lejdzie ${ }^{31}$.

Bedeutungsforschung, Bd. 65), hrsg. W. Harms, D. Peil, Frankfurt am Main 2002 s. 757; Tenże, Jakob von Bruck-Angermundt und seine Emblembücher, [w:] Die oberschlesische Literaturlandschaft im 17. Jahrhundert, hrsg. G. Kosellek, Bielefeld 2001, Tagungsreihe der Stiftung Haus Oberschlesien, Bd. 11, s. 139, 146, 153.

31 Nie miejsce tu wprawdzie, aby wyliczać wszystkie utwory i publikacje, które powstały w czasie akademickich peregrynacji braci Cyganów i w których wymieniono ich nazwiska, wypada jednak - poza wspomnianymi już drukami J. Brucka Angermundta - wskazać przynajmniej: C. Barlaeus, Poemata, tum quae antehac edita fuerunt: tum quae jam singulari libro nova in lucem prodierunt, T. 1, Lugduni Batavorum 1630, s. 109-113; M. Bernegger, Collegivm Politicum Lipsianum In Inclytâ Argentoratensi Academiâ ab Illustribus, Generosis, Nobilissimis Atqve Florentissimis juvenibus quibusdam institutum, Moderante M. Matthia Berneggero, Argentorati 1617, k. ):(2-):(2v.; Tenże, J.J. Cygan, Iusti Lipsii Politicorum Liber I. De duobus civilis vitae directoribus, Virtute \& Prudentia, cu[m] annexis / a Joanne Georgio Czigan, L.B. de Slupska \&c: In aphorismos redactus, $\&$ in Illustri Argentoratensium Academia, Propositus ad examinandum, Praeside Matthia Berneggero, Historiarum In eadem Prof. Ordinario, Argentorati 1616; C. Bitsch, A. Scholl, De Codicillis Et Clausula Codicillari, Disputatio III. Tractans de causis, materiali \& formali / De qua ... In alma Academia patria, Praeside Casparo Bitschio I.U.D. ... Publice respondebit Die Martii Andreas Schollius Argentoratensis, Argentorati 1617, k. Av.; J.P. Crusius, J.T. Obrecht, Daphnis Seu Actus Caesareus Sacratißima Sacratißimae Caesareae Maiestatis Authoritate A Iohanne Thoma Obrechto Iureconsulto Argentoratense ... in Actoasi nova celebratus: / Quo Johanni Paulo Crusio Argentoratensi Liberalium Artium Magistro ... Antiquissimum illud, dignissimum, \& nunquam emoriturum Poetarum Praemium Corona Laurea ..., Argentorati 1616, k. [F6] ; J. Meier, Pandectarvm Vniversi Ivris Civilis, Sive Collegii Ivridici Argentoratensis. Omne Jus Pandectarum, Quodque Eidem Ex Codic. Instit. Novell. Justinianeis respondet, una perpetuaque causarum methodo dispositum: cum supplemento Juris tum Canonici, tum Novissimi ex Imperial. Constit. \& forensibus observationibus, exhibentis: Tomus Posterior : In Academia Argentoratensi A Doctissimis Iuris Candidatis Ac studiosis perfectus \& recensitus cura Iusti Meieri Noviomagensis I.U.D. ..., Argentorati 1617, k.):(2; J. Othonia, Johannae Othoniae, Foeminae Flandriae. Viri Clarissimi, Domini Guilielmi Mayarti, In Provinciali consilio Flandriae quondam Advocati consultissimi, Carminum Diversorum Libri Duo, Argentorati 1616, k. Ev.; Tacyt, C. Cornelii Taciti De Vita ..., k. S2 (2. wyd. 1618). 
Z czasem, już po powrocie ze studiów, mimo trudnego wojennego czasu i materialnego upadku, jaki stał się udziałem braci Cyganów, także wokół ich dworów formować zaczął się krąg ludzi pióra. Jakkolwiek uzasadnione może być doszukiwanie się podobieństw owego środowiska $\mathrm{z}$ kręgiem literatów skupionym wokół A. Kochcickiego, wyraźne są także dzielące je różnice. Przede wszystkim grupa poetów związanych z Cyganami była nieporównanie szczuplejsza i ograniczała się w istocie do trzech tylko nazwisk: wspomnianych już D. Czepki ${ }^{32}$ i W. Scherffera ${ }^{33}$ oraz - najmniej znanego Adama Büthnera, pełniącego na zaproszenie braci Cyganów funkcję pastora i superintendenta we Frysztacie ${ }^{34}$. Po wtóre, jedynie obecność tego ostatniego w otoczeniu panów ze Słupska można wyjaśnić względami praktycznymi, dwaj pozostali zaś przebywali na dworze Cyganów chyba tylko w charakterze rezydentów, przyjaciół rodziny, nie pełniając jednocześnie żadnych obowiązków związanych ze swoim powołaniem czy profesją ${ }^{35}$. Owa bliskość,

32 K.T. Strasser: Der junge Czepko, ,Münchener Archiv für Philologie des Mittelalters und Renaissance“, hrsg. F. Wilhelma, H. 3, München 1913, s. 44-48; W. Milch, Daniel Czepko..., s. 9-15; G. Hultsch, Daniel Czepko von Reigersfeld 1605-1660, „Jahrbuch für Schlesische Kirchengeschichte“, 1960, s. 92-97; A. Meier, Daniel Czepko als geistlicher Dichter, Bonn 1975, Studien zur Germanistik, Anglistik und Komparatistik, Bd. 33, s. 11-12; U. Seelbach, Die Ermittlung personenbezogener..., s. 226-227; M. Stebler, Andreas Gryphius i Daniel Czepko, [w:] Dawna kultura literacka na Ślasku. Zbiór studiów, pod red. M. Borysiak i A. Galosa, Wrocław 1994, s. 81-83; Tenże, Daniel Czepkos Coridon und Phyllis. Eine Analyse des Epos mit Strophenkommetar zum Ersten Buch, Wrocław 1995, Acta Universitatis Wratislaviensis, no 1752, Germanica Wratislaviensia, CXIII, s. 9, 12, 30-31.

33 J. Piprek, Wactaw Scherffer von Scherfferstein. Poeta ślaski i polonofil XVII wieku, Opole 1961, s. 60-64; W. Scherffer von Scherfferstein, Geist- und weltlicher Gedichte. Erster Teil, Brieg 1652, hrsg. E. Pietrzak, Tübingen 1997, s. 6*-12*.

34 W. Magirus, Desiderium Terrae Viventium, Hertzliches verlangen/ nach dem Lande der Lebendigen. Das ist Eine Christliche Leichpredigt/ auß dem 12. und 13. vers des Sieben und Zwantzigsten Psalms Davids : Gehalten/Uber dem Seligen abschiede/ und Christlicher Leichbegängnis/ Des Weyland Ehrwürdigen/ Achtbarn und Wolgelarten Herrn M. Adami Büthneri, Poetae. L.C. trewfleißigen und verdienten Pastoris, der Kirchen Christi/ in der Dantzker Vestung Weisselmünde. Welcher Anno Christi 1643. den 5. Sontag nach Trinitatis zwischen 9. und 10. Uhren des Morgens unter wehrendem Gottesdienste/ in wahrem glauben/ und Standhaffter Bekentnis Jesu Christi sanfft und stille/ bey guter vernunfft sein leben beschlossen/ und den folgenden Mittwoch/ war der 8. Julii mit Christlichen Ceremonien zur Erden bestattet, Dantzig 1644, s. 52-53; G. H. Götzen, Diptycha Exulum, Oder Exulanten-Register, Darinnen die Nahmen derer Beständigen Lutheraner angeschrieben stehen, Welche Um der Lehre des Evangelii willen, zwar verfolget, und ins Elend vertrieben worden, doch gleichwohl aber Göttl. Beschirmung und Seegen mit denen Ihrigen wieder gefunden haben ... Nebst Einer Exulanten-Predigt über Matth. XIX. v. 29., Altenburg 1714, s. 61-62; W. Scherffer von Scherfferstein, Geist- und weltlicher Gedichte..., s. 11*-12*; M. Pawelec, Büthner Adam, [w:] Stownik pisarzy ślaskich, pod red. J. Lyszczyny i D. Rotta, T. 3, Katowice 2010, s. 19-21.

35 W literaturze uporczywie wraca twierdzenie, iż D. Czepko pełnił w Dobrosławicach, często przy tym błędnie identyfikowanych z miejscowością o tej samej nazwie położoną niedaleko Koźla, rolę domowego nauczyciela, co - zważywszy, że w otoczeniu braci Cyganów nie było młodzieży ani dzieci, których edukacją mógłby się zajmować - nie wydaje się możliwe, por. np.: A. Meier, Daniel Czepko..., s. 11; F. van Ingen, Daniel von Czepkos Consolatio ad Baronissam Cziganeam. Tröstung, 
może wręcz przyjaźń łącząca twórców z ich patronami znalazła też swój wyraz w dość osobistym tonie dedykowanych im utworów, czemu zresztą sprzyjała gatunkowa i językowa przynależność twórczości tak D. Czepki, jak i W. Scherffera, z oczywistych względów zaliczanych już do niemieckiego baroku. I to trzecia zasadnicza cecha odróżniająca literatów i literaturę powstającą w kręgu braci Cyganów oraz A. Kochcickiego, którego otaczali jeszcze humanistyczni poeci łacińscy.

Czy jednakże J.J. Cygan, naśladując A. Kochcickiego w swoich literackich i mecenasowskich aspiracjach, podzielał także jego pasje bibliofilskie, które w przypadku pana z Kochcic zaowocowały powstaniem słynnej, opisanej przez Fryderyka Lucae kolekcji książek, uznawanej za jedną z największych podówczas bibliotek szlacheckich na Śląsku? Wszak to ona przede wszystkim miała na dwór Kochcickiego przyciągać śląskich pisarzy ${ }^{36}$. W poszukiwaniach odpowiedzi na to pytanie ponownie w sukurs przychodzi nam D. Czepko, który w poświęconym panu ze Słupska epitafium, oddawszy hołd uczoności swojego patrona, mającego jakoby inspirować, a nawet udzielać rady uczonym tej miary co Matthias Bernegger, Justus Meier oraz Filip Clüver, pisze:

Dein Königreich / dein Rath

War unter tausend Büchern

Sich seiner Lust versichern /

Gleich wie Lucullus that ${ }^{37}$,

wcześniej już zaznaczywszy, iż:

Der Bücher schöne sachen

Berührten deinen Sin I

$D a ß d u$ von Händen hin /

Ihr urtheil köntest machen ${ }^{38}$.

Jest oczywiste, że podkreślanie znawstwa ksiąg i przywiązania do nich należało do klasycznych komplementów, którymi w literaturze okolicznościowej obdarzani bywali patroni poetów i pisarzy. Wszak adresatem podobnych pochlebstw był również A. Kochcicki, o którym pisano, że „E. G. In lectione sacra täglich und fleissig versiren”39, w innym miejscu zaś dodawano: ,in Lectione tam sacra, quam politica, täglich vnd fleissig versiren, vnd in ihrer lustigen

Rhetorik, Psychologie, [w:] Die oberschlesische Literaturlandschaft..., s. 200; S. Wollgast, Zur Kasualdichtung und Kasualrede bei und um Daniel Czepko, [w:] Theorie und Praxis der Kasualdichtung in der Frühen Neuzeit, hrsg. A. Keller i in., Amsterdam, New York 2010, Chloe, 43, s. 212.

36 Por.: K. Szelong, Andreas Kochtitzki..., s. 376-377.

37 D. Czepko, Auff Deß Wolgebohrnen Herren ..., bp.

38 Tamże.

39 N. Tilesius, PfingstPredigten : In welchen aus dem Alten und Newen Testament/Lehrhafftige und Trostreiche Sprüche/ auff dasselbige gnadenreiche Fest gerichtet/ gehandelt werden / Gehalten In unterschiedlichen Jahren ... Durch M. Nathanaëlem Tilesium ..., Breslau, Leipzig 1611, k. Biii. 
Bibliotheca alle Faculteten wol disponiret, vnd reichlich besetzet" ${ }^{40}$. Mimo swej konwencjonalności, tego rodzaju pochwały musiały więc zachowywać związek z rzeczywistością, czego przykład właściciela Koszęcina jest najlepszym dowodem. Również komplementy D. Czepki zdają się w pewnej przynajmniej mierze znajdować pokrycie w faktach. Nie byłoby w tym zresztą nic dziwnego. Wszak poeta przez dłuższy czas przebywał w najbliższym otoczeniu J.J. Cygana i jako jego przyjaciel był świadom upodobań gospodarzy dobrosławickiego dworu. Ujawnia to już choćby ujmujące, choć zważywszy na materialną mizerię, w jakiej znajdowali się wówczas Cyganowie, dość karkołomne odniesienie do Lukullusa, do którego pan ze Słupska mógł się porównywać o tyle, że pośród politycznych i religijnych zawirowań, boleśnie doświadczających Śląsk w czasie wojny trzydziestoletniej, inaczej niż młodszy brat Karol Henryk, a zwłaszcza obaj Andrzejowie Kochciccy, którzy bez reszty zaangażowali się w antyhabsburską opozycję ${ }^{41}$, sam - podobnie jak starożytny bohater - trzymał się z dala od publicznej aktywności i osiadłszy na śląskiej prowincji, oddawać miał się rozkoszom wiejskiego życia, studiom i rozmyślaniom, kontaktów szukając raczej z ludźmi pióra niż miecza.

Czy jednak, podobnie jak Lukullus, również J.J. Cygan stworzył okazały księgozbiór, czy też zdanie „Dein Königreich / dein Rath War unter tausend Bůchern", mogące sugerować, że otaczał się książkami, jest tylko przenośnią, obrazującą zamiłowanie pana ze Słupska do lektury? Także w wyjaśnieniu tej sprawy z pomocą przychodzi nam D. Czepko. Otóż wiele lat po śmierci swojego niegdysiejszego protektora, gdy poeta przebywał już na stałe w rodzinnej Świdnicy, angażując się m.in. w sprawę budowy w tym mieście Kościoła Pokoju, a zarazem ubiegając się o nobilitację, w obu sprawach kontaktować się musiał ze starostą ziemskim księstwa jaworsko-świdnickiego Ottonem Nostitzem młodszym ${ }^{42}$ i, zapewne by zyskać przychylność starosty, któremu zresztą przyobiecał dostarczenie egzemplarzy swoich prac (zauważając, że ich liczba jest bliska stu), w skierowanym do niego - prawdopodobnie w 1650 r. - liście napisał, co następuje:

40 N. Monardes, Ein nützlich und lustig Gespräche/ Von Stahl und Eisen : Darinnen dieser Metallen Würdigkeit und ArtzneyTugenden angezeiget werden / Erstlich in Spanischer Sprache geschrieben/von ... Nicolao Monardo, und vor wenig Jahren in die Lateinische gebracht/ durch ... Carolum Clusium, Jetzo aber ... in unsere Deutsche Sprache versetzt ... durch Jeremiam Gesnerum ... Sampt einem andern Tractätlin/Von dem Schnee und Eyß ..., Leipzig, Breslaw 1615, k. Aiii.

41 J. Zukal, Die Lichtensteinische Inquisition in den Fürstentümern Troppau und Jägerndorf aus Anlaß der Mansfeldischen Rebellion 1626-1627, „Zeitschrift für Geschichte und Kulturgeschichte Österreichisch-Schlesiens“, 1912, H. 1/3, s. 37, 50-51; Tenże, Paméti opavské, s. 88; Tenże, Slezské konfiskace 1620-1630. Pokutovani provinilé šlechty v Krnovsku, Opavsku a Osoblažsku po bitvě bělohorské a po vpádu Mansfeldové, V Praze 1916, s. 67, 74, 99; R. Fukala, Ozvěny chebských události ve Slezsku, „Historica. Revue pro historii a př́buzné vědy”, 1/1, 2010, s. 6; K. Szelong, Andreas Kochtitzki..., s. 385-391.

42 W. Milch, Daniel Czepko..., s. 20-21, 26, 31. 
Ex manuscriptis Baronis Czigani quondam mei librum de nobilitate autographum interim, sed heu vix completum mitto: missurus olim alterum, quamprimum ex superiore Silesia cum pagellis unis alterisque in priore opere desideratis aderit. Apud eundem Baronem Cziganeum et typis exscriptum latine, et manu descriptum germanice his in manibus, oculis habui iisque usurpavi: uterque liber sub filiae Captivi Logtiovicl nomine Virginis alias propter literas satis laudatae, utpote quae $\mathrm{Cl}$ (arissimum) Cluverum Lugdunensem deinceps Professorem pro Informatore habuit, qui et Autor scripti illius habetur. ${ }^{43}$

Zacytowany ustęp, jakkolwiek nie jest całkiem jasny, zdaje się dowodzić, że - po pierwsze - J.J. Cygan, nazywany przez D. Czepkę „,moim” - w domyśle przyjacielem, był właścicielem jakiegoś zbioru rękopisów, skoro poeta przesłał O. Nostitzowi książkę „o szlachcie” - własnoręcznie napisaną (przepisaną?), lecz niezupełnie jeszcze gotową - a pochodzącą „ex manuscriptis Baronis”, do którego to zbioru, co więcej, D. Czepko jeszcze dziesięć lat po śmierci właściciela miał dostęp, bo oczekiwał na odebranie z Górnego Śląska drugiej książki (drugiej części książki „o szlachcie”?) wraz z brakującymi stronami pierwszej z wymienionych, zapowiadając zarazem przesłanie tychże materiałów Nostitzowi, po wtóre zaś zbiór ten zawierać musiał rzeczy cenne, a może wręcz unikatowe, o czym zaświadcza nie tylko istnienie jakiegoś godnego uwagi tak wytrawnego kolekcjonera, jakim był O. Nostitz rękopisu na temat szlachty, ale przede wszystkim obecność w owym zbiorze apologii Jerzego Popela Lobkowicza, i to zarówno w postaci niemieckojęzycznego rękopisu, jak i ogłoszonego drukiem łacińskiego przekładu. Chodzi o dzieło zatytułowane Apologia Pro Georgio Popelio Barone De Lobkovitz, regni Boiohaemiae quondam supremo aulae praefecto; post ab imperatore Rudolfo Secundo, Hungariae ac Boiohaemiae Rege, per duodecim annos, contra ius fasque carcere adtento: Ad Reges, Principes, Ceterosq[ue] Christiani nominis mortaleis, mające pochodzić rzekomo spod pióra Philaretesa Amyntasa Codomanusa, pod którym to pseudonimem w rzeczywistości ukrywał się Filip Clüver. Choć nie ma pewności, czy ten ostatni faktycznie apologię napisał, czy też tylko przełożył na łacinę tekst przygotowany już wcześniej z inspiracji córki uwięzionego J. Popela Lobkowicza, Ewy Euzebii (albo wręcz - jak chcą niektórzy badacze - przez nią samą opracowany), publikacja, która wyszła drukiem w Lejdzie w 1606 r., ściągnęła na głowy tak obojga Lobkowiczów, jak i Clüvera gniew Rudolfa II, a sama książka była zapewne ścigana i jej egzemplarze stały się rzadkością ${ }^{44}$.

43 D. Czepko, Sämtliche Werke, Bd. 6: Briefwechsel und Dokumente zu Leben und Werk, Berlin - New York 1995, s. 92-93, R. Fukala, Stavovská politika na Opavsku v letech 1490-1631, Opava 2004, s. 91.

44 P. Fuchs, Clüver Philipp, [w:] Neue Deutsche Biographie, 3 (1957), s. 295-296; T. Bedyński, Gdański geograf Filip Kluwer (1580-1622) twórca granic wspótczesnej Europy, Warszawa 2002, s. 21-23. 
Zgromadzony przez O. Nostitza w Jaworze księgozbiór, już za jego życia należący do największych bibliotek szlacheckich na Śląsku i obfitujący w dzieła cenne i rzadkie, by wymienić choćby tylko autograf De revolutionibus Mikołaja Kopernika czy egzemplarz Biblii Gutenberga, po śmierci właściciela stał się podstawą majorackiej biblioteki Nostitzów, którą stworzył przyrodni brat Ottona, Jan Hartwig (1610-1683), przenosząc zarazem zbiór do Pragi, gdzie biblioteka również obecnie jest przechowywana, od 1954 r. wchodząc w skład Muzeum Narodowego ${ }^{45}$. Niestety, poszukiwanie w jej zasobie prac wymienionych w liście D. Czepki pozostało bezowocne, niemniej z innego powodu ślad wiodący do kolekcji O. Nostitza okazał się wielce fortunny. Otóż, czeski bibliolog Richard Šípek, który w swojej wydanej przed kilkoma laty imponującej monografii poświęconej jaworskiej bibliotece O. Nostitza uwzględnił m.in. odnalezione we wrocławskiej bibliotece uniwersyteckiej książki opatrzone oznaczeniami proweniencyjnymi zbieżnymi z tymi, które występowały także w zachowanej w Pradze kolekcji Nostitza, wśród dzieł będących niegdyś własnością świdnickiego prawnika Ehrenfrieda Ferdinanda Machfrieda wymienił dwa, które wcześniej stanowiły własność... J.J. Cygana. Wprawdzie E.F. Machfried swój podpis w obu książkach umieścił w 1664 r., a więc ledwie rok przed śmiercią O. Nostitza, a zarazem 17 lat po opatrzeniu swoimi znakami siedmiu książek, które stały się własnością świdnicko-jaworskiego starosty, co zdaje się wskazywać, że oba zachowane we Wrocławiu druki nie wchodziły jednak w skład biblioteki Nostitzów. Oba natomiast trafić musiały do Świdnicy, w której mieszkał E.F. Machfried i gdzie zasiadał w radzie miejskiej. Nie od rzeczy więc będzie postawić pytanie, choćby miało ono pozostać bez odpowiedzi, czy dzieła z Cyganowską proweniencją nie trafiły do Świdnicy za sprawą D. Czepki, który był także z tym miastem ściśle związany, bez wątpienia musiał się z E.F. Machfriedem znać, a zmarł już w 1660 r.? ${ }^{46}$

Oznaczenia własnościowe J.J. Cygana, którymi opatrzone zostały wymienione przez R. Šípka książki, są dwojakiego rodzaju. W obu znaleźć można dokonane czerwonym atramentem wpisy na stronach tytułowych, obie też opatrzone są dodatkowo złoconym superekslibrisem herbowym odciśniętym pośrodku obu okładzin pergaminowych opraw. Pierwsza z książek, nosząca sygnaturę 494652, to De republica libri sex et viginti autorstwa Pierre'a Grégoire'a, wydana w 1609 r. we Frankfurcie nad Menem. Na jej stronie tytułowej widnieje wpis następującej treści: „Ex bibliotheca Johannis Georgii Czigan L.[iberi] B.[aronis] de Slupska Emptus Argentorati M.[ense] Novembr.[is]

45 J. Cejpek, I. Hlaváček, P. Kneidl: Dějiny knihoven a knihovnictví v českých zemich a vybrané kapitoly z obecných dějin, Praha 1996, s. 117-118; R. Šipek, Die Jauerer Schlossbibliothek Ottos des Jüngeren von Nostitz, T. 1, Frankfurt am Main 2014, s. 41-42, 47-85.

46 Tamże, s. 141, 205; T. 2, s. 396. 
1614. 2 thl. sles. $10 \mathrm{~g} /$ ”. Druga książka, przechowywana w Bibliotece Uniwersyteckiej we Wrocławiu pod sygnaturą 468994, to wydana w 1606 r. we Frankfurcie nad Menem Baltazara Castiglione De curiali sive aulico libri quatuor w przekładzie Bartholomew Clerke'a. Widniejący na jej stronie tytułowej napis brzmi: „Inservio Johanni Georgio Czigan L.[ibero] B.[aroni] de Slupska. Emptus Argentorati M.[ense] Mart.[ii] 1615. 16 g/.”. Na stronach tytułowych obu książek widnieją ponadto wpisy ich późniejszego właściciela o powtarzającej się treści: „Ehrefr.[edi] Ferd.[inandi] a Machfrid. Anno 1664." ${ }^{47}$.

Il. 2. Superekslibris J.J. Cygana zdobiący oprawę dzieła P. Matthieu, Histoire de France, et des choses memorables aduenues aux prouinces estrangeres durant sept annees de Paix, dv regne dv roy Henri IIII. roy de France et Nauarre, Cologny 1613. Źródło: Książnica

Cieszyńska, sygn. SZ 2 P VI 36/01. Zdjęcie: Anna Fedrizzi-Szostok
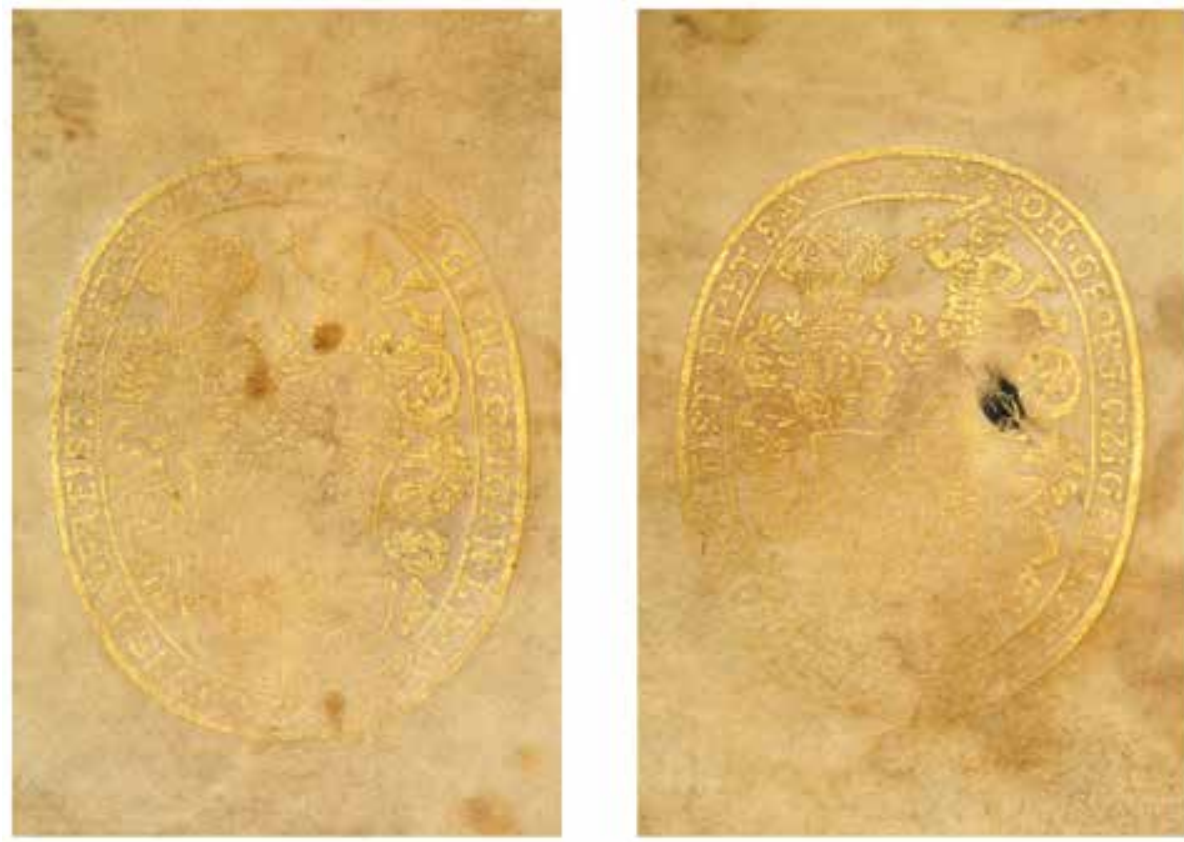

Zdobiący oprawy obu książek superekslibris ma owalny kształt o wymiarach 51 na $42 \mathrm{~mm}$. W jego otoku wytłoczono napis: „JOH.[annes] GEORG. [ius] CZIGAN L.[iber] B.[aro] DE SLUPSKA D[omi]N[u]S IN FREISTADT ET SAW[a]DA", a wewnątrz odciśnięto pięciopolowy herb, w którym do godła Kiczka, przedstawianego w heraldycznych polach prawym górnym i lewym dolnym, zostało dodane w polach lewym górnym i prawym dolnym godło

47 Tamże; za pomoc w odszukaniu i identyfikacji obu wrocławskich książek z Cyganowską proweniencją dziękuję Pani Dr Lucynie Biały z Biblioteki Uniwersyteckiej we Wrocławiu. 
obrazujące odzianą w szamerowany kaftan i kapelusz lub kołpak postać, która trzymając się pod bokiem lewą ręką, prawą - uzbrojoną w turecką szablę unosi ku górze. Na środku tarczy umieszczone zostało jeszcze jedno pole, w którym wyobrażono kotwicę. Uzbrojona postać, ukazana powyżej kolan, znalazła się także w klejnocie, obok trzech strusich piór, przy czym wyobrażenie wojownika wieńczyło lewy, a piór - prawy hełm, które dodatkowo przystrojone były koronami oraz labrami. Zdobiące tarczę herbową hełmy mają kształt turniejowy.

Takie przedstawienie herbu J.J. Cygana pozostaje całkowicie zgodne z opisem zawartym w konspekcie dyplomu baronowskiego (oficjalna wersja dyplomu nie zachowała się do czasów współczesnych), na podstawie którego w 1611 r. ród Cyganów podniesiony został do stanu pańskiego, otrzymując prawo posługiwania się tytułem „Freiherr”, a rodzinny herb Kiczka (w dawniejszej literaturze błędnie identyfikowany z Kietliczem ${ }^{48}$ ), przedstawiający na błękitnym polu trzy węzły złotego powroza czy sznura, został udostojniony poprzez dodanie elementów widniejących m.in. w zaprezentowanym tu superekslibrisie ${ }^{49}$. Kluczowym elementem tego zabiegu stało się umieszczenie w pięciopolowym odtąd herbie wizerunku postaci, która - zgodnie z opisem zawartym w konspekcie dyplomu baronowskiego - przedstawia Cygana (!), choć wizerunek ów pozostaje nader zbieżny z heraldycznym wyobrażeniem Turka, pojawiającym się w wielu ówczesnych herbach. Nie od rzeczy będzie więc w tym miejscu dodać, że przydomek Cygan miał w 1481 r. od Macieja

48 Za nieporozumienia w tej kwestii odpowiedzialny jest chyba Bartosz Paprocki, który chcąc zapewne dowieść „starodawności i znaczności” rodów pieczętujących się herbem Kiczka, wywiódł ich genealogię z łużyckich Kietliczów (Kittlitz), mimo iż ród ów używał innego herbu, z tarczą dzieloną w skos, wyobrażającego z prawej strony pół bawołu, a z lewej skośne belki, którego opis również zanotował B. Paprocki, nie siląc się wszakże na wyjaśnienie przyczyn wynikających stąd rozbieżności, B. Paprocki: Herby rycerstwa polskiego, Kraków 1858, s. 670, 672; przekaz B. Paprockiego okazał się niezwykle żywotny i w literaturze heraldycznej nadal pozostaje źródłem niejasności. Ich efektem jest w najlepszym razie bezradność heraldyków wobec wyboru prawidłowej nazwy herbu (np. Józef Szymański odnotował bez żadnego komentarza, że herb Kiczka przez Bartosza Paprockiego i Franciszka Piekosińskiego nazywany jest także Kietliczem: J. Szymański, Herbarz średniowiecznego rycerstwa polskiego, Warszawa 1993, s. 148; por. też: J. Horwat, Z. Jedynak, Z. Kiereś, Genealogia kilku rodzin szlacheckich z ziemi gliwickiej, toszeckiej i bytomskiej (cz. 3), „Zeszyty Gliwickie", 31, Gliwice 2003, s. 23, L. Igálffy-Igály, Die Kiczka-Karwinsky..., s. 30), w najgorszym zaś razie - identyfikowanie Kietliczów łużyckich z górnośląskimi rodami pieczętującymi się Kiczką (np. Stanisław Kozierowski przytacza bezkrytycznie informację B. Paprockiego, iż zamieszkały w księstwie oświęcimskim ród Skidzińskich wywodzi się z tego samego pnia co Kietliczowie łużyccy: S. Kozierowski, Obce rycerstwo w Wielkopolsce, Poznań 1929, s. 47; por. też np.: Neues allgemeines Deutsches Adels-Lexicon, hrsg. E. H. Kneschke, Bd. 2, Leipzig 1860, s. 391; J.G.Th. Graesse: Geschlechts-, Namen- und Wappensagen des Adels Deutscher Nation, Dresden 1876, s. 190).

49 Österreichisches Staatsarchiv (dalej: ÖStA), Hofadelsakt Czigan von Slupska 1611, sygn. AT-OeStA/AVA Adel HAA AR 172.7; por.: K.F. v. Frank, Standeserhebungen und Gnadenakte für das Deutsche Reich und die österreichischen Erblande bis 1806 mit einigen Nachträgen zum „Alt-Österreichischen Adels-Lexikon“ 1823-1918, Bd. 2: F-J. Schloss Senftenegg 1967, s. 213. 
Korwina otrzymać Jan Żegota, spieszący na czele oddziału złożonego z zebranych naprędce Cyganów na pomoc walczącemu z Turkami królowi. Maciej Korwin miał wówczas na jego widok zakrzyknąć: „Adesdum Zygane?! Du bist hier Zigeuner?!". Wydarzenie to zapoczątkowywało jakoby historię nowej linii rodu Żegotów, której członkowie nosili nazwisko Cygan i stać się miało podstawą ich rodowej legendy, do której nawiązanie pojawiło się w udostojnionym w $1611 \mathrm{r}$. herbie ${ }^{50}$.

Wrocławskie książki ozdobione superekslibrisem J.J. Cygana nie są jedynymi, jakie zachowały się do czasów współczesnych. Już na początku lat 90. XX w. tom opatrzony identycznym znakiem własnościowym piszący te słowa odnalazł w bibliotece ks. Leopolda Jana Szersznika, wchodzącej obecnie w skład Książnicy Cieszyńskiej ${ }^{51}$. Ten superekslibris jest jednak znacznie gorzej zachowany, pergaminowa oprawa przybrudzona i sfałdowana, a złocenia i tłoczenie w większej części zatarte. W odróżnieniu od woluminów zachowanych we Wrocławiu książka nie została oznaczona wpisem własnościowym J.J. Cygana, a na jej stronie tytułowej widnieje tylko naniesiona ręką ks. L.J. Szersznika notka o treści: „Bibliothecae Scherschnickianae Dono D. Max. L.B. de Gotschalkovsky", wskazująca, że książka ta, podobnie jak wiele innych druków, rękopisów i muzealiów, trafiła do biblioteki cieszyńskiego jezuity dzięki hojności marszałka ziemskiego księstwa cieszyńskiego barona Maksymiliana Goczałkowskiego. W tym przypadku chodzi o wydany w Kolonii w 1613 r. tom pierwszy dzieła Pierre'a Matthieu, zatytułowanego Histoire de France, et des choses memorables aduenues aux prouinces estrangeres durant sept annees de Paix, dv regne dv roy Henri IIII. roy de France et Nauarre, który nosi sygnaturę SZ 2 P VI 36/01.

Do tej pory udało się zatem zlokalizować łącznie trzy książki opatrzone superekslibrisem J.J. Cygana. Jak się wydaje, wszystkie nabyte zostały przez niego w podobnym czasie i miejscu, prawdopodobnie krótko po tym, kiedy śląski arystokrata pojawił się w Strasburgu. Wskazują na to nie tylko daty wydania zamykające się pomiędzy latami 1606 i 1613, świadczące, iż w drugiej dekadzie XVII w. książki znajdowały się jeszcze w obiegu księgarskim, ale przede wszystkim notatki rękopiśmienne, którymi J.J. Cygan opatrzył dwie spośród

50 B. Paprocki, Zrdcadlo slawneho Margkrabstwij Morawskeho w kteremż geden każdy staw, dawnost, wzactnost y powinnost swau vhleda / kratce sebrane a wydane roku 1593 skrze Bartholoměge Paprockeho..., Olomvtii 1593, k. 325; J. Sinapius, Des schlesischen Adels anderer Theil..., s. 498; J.G.Th. Graesse, Geschlechts-, Namen- und Wappensagen..., s. 190; J. Pilnáček, Rody starého Slezska..., T. 3, s. 131.

51 O bibliotece ks. Leopolda Jana Szersznika zob.: K. Szelong, Biblioteczne zbiory Leopolda Jana Szersznika, [w:] 190 lat założenia Muzeum i Biblioteki Leopolda Jana Szersznika 1802-1992, pod red. J. Spyry, Cieszyn 1993, s. 37-52; M. Makowski, J. Spyra, K. Szelong, Zbiory i Fundacja Szersznika po 1814 r., Tamże, s. 81-90; K. Szelong, Proces ewidencji i opracowania bibliotecznych zbiorów ks. Leopolda Jana Szersznika. Zarys historyczny, „Roczniki Biblioteczne”, 2000, s. 87-134. 
kupionych publikacji. Wynika z nich, że druk, który został przez niego nabyty jako pierwszy, trafił w jego ręce już w listopadzie 1614 r., a więc niemal natychmiast po przyjeździe do Strasburga. Kolejny kupił cztery miesiące później, w marcu 1615 r. O czasie nabycia trzeciej książki, przechowywanej obecnie w Cieszynie, nie da się niczego powiedzieć, ponieważ właściciel nie opatrzył jej żadną notatką. Fakt ten nasuwać może jednak hipotezę, iż po wejściu w posiadanie dzieła P. Matthieu oddał go wraz z wcześniej nabytymi drukami $\mathrm{W}$ ręce introligatora, zlecając opatrzenie wszystkich woluminów superekslibrisem, co - w jego odczuciu - likwidować mogło potrzebę własnoręcznego podpisywania książki. W każdym razie oprawy, podobnie jak superekslibris, są identyczne, co zdaje się wskazywać, iż wyszły z tego samego warsztatu.

Na pytanie, czy książek zaopatrzonych w superekslibris J.J. Cygana było więcej, nie sposób tymczasem odpowiedzieć. Wysoce prawdopodobne wydaje się jednak, że zlecenie wykonania ozdobionych złoconym herbem opraw było rezultatem kaprysu, decyzji podjętej jednorazowo, być może już w Strasburgu, na przykład z uwagi na pojawiające się tam techniczne możliwości realizacji tego rodzaju zamysłu, ale chyba przede wszystkim z potrzeby zyskania przez młodego arystokratę jeszcze jednego instrumentu godnego właściwego jego stanowi zaprezentowania się w nowym środowisku. Podkreślić jednak należy, że to tylko hipoteza wymagająca dalszych badań, zwłaszcza zaś analizy formalno-technicznych aspektów zachowanego superekslibrisu, która pozwoli być może na zidentyfikowanie miejsca jego powstania, a do której przeprowadzenia piszący te słowa nie czuje się powołany. W każdym razie, zastanawiając się nad genezą superekslibrisu J.J. Cygana pamiętać należy, iż działał tu z całą pewnością przykład A. Kochcickiego seniora, który w analogiczny sposób oznaczał i ozdabiał swoją bibliotekę, wyposażając zebrane książki w pergaminowe oprawy, na których - jak zauważył F. Lucae - połyskiwała złoceniami herbowa Czapla Kochcickich ${ }^{52}$.

52 F. Lucae w swojej kronice odnotował, iż A. Kochcicki „,..] ließ die weitleufftige Livrée durchgehend in grün gefärbtes Pergament sauber einbinden, äußerlich die Bücherschalen fein vergülden und auff dieselben sein Wappen ebenfalls mit Gold eindrucken, welches gewiß sehr nette in die Augen leuchtete und den Büchersaal ganz ungemein zierete“, F. Lucae, Schlesiens curieuse Denckwürdigkeiten/ oder vollkommene Chronica von Ober- und Nieder-Schlesien/: welche in Sieben Haupt-Theilen vorstellet Alle Fürstenthümer und Herrschafften/ mit ihren ... Landes-Fürsten ... Geschlechtern ... Wappen ... / Ausgefertiget von Friderico Lucae, Franckfurt am Mäyn 1689, s. 649. Jakkolwiek nie wiadomo, czy śląski kronikarz miał okazję zetknąć się z większą liczbą książek pochodzących z biblioteki A. Kochcickiego, czy też opis ten sporządził na podstawie innych znanych sobie źródeł, jego przekaz wydaje się wiarygodny; przemawiają za tym cechy zewnętrzne „kochcickianów" zachowanych w zbiorach Biblioteki Uniwersyteckiej we Wrocławiu: wszystkie one oprawne są w zielony pergamin, a na ich okładkach widnieje owalny superekslibris o wymiarach 55 na $40 \mathrm{~mm}$, przedzielony poprzecznym ornamentem z baronowską koroną i przedstawiający - w dolnej i górnej części - wizerunki herbowej czapli Kochcickich siedzącej na pniu i trzymającej w dziobie rybę. W otoku superekslibrisu znajduje się inskrypcja: „Andreas a Kochticz in Kossenczin et Turna- 
Na podstawie kilku zaledwie książek nie sposób także w sposób odpowiedzialny wypowiedzieć się na temat czytelniczych zainteresowań i preferencji ich właściciela, choć - zważywszy na fakt, iż książki zostały zakupione tuż po przybyciu J.J. Cygana do Strasburga - świadczyć mogą o intelektualnych aspiracjach towarzyszących mu na początku zagranicznego etapu jego edukacji. Chęć posiadania Dworzanina Baltazara Castiglione, będącego swego rodzaju przewodnikiem dla wkraczających w świat młodych arystokratów, jest w tym kontekście całkowicie zrozumiała i nie wymaga komentarza. Bardziej intrygujące wydają się za to dzieła P. Grégoire'a oraz P. Matthieu, wskazujące, iż uwaga młodego szlachcica skierowana była w tym czasie na zagadnienia polityczne, kwestie ustrojowe i rolę władzy, co wyjaśniać można zarówno narastającym wówczas w Europie kryzysem wyznaniowym i politycznym, przekładającym się na intelektualny ferment obecny także na dworach szlachty śląskiej i przejawiane przez nią zainteresowania, jak i -zapewne - potrzebami edukacyjnymi. Wszak frysztacki baron trafił w Strasburgu pod opiekę Matthiasa Berneggera i zgłębiając pod jego kierunkiem pisma Tacyta, zapoznawał się jednocześnie z politycznym neostoicyzmem, w którego duchu można odczytywać obie powyższe książki. Zwraca ponadto uwagę fakt, iż oba dzieła pochodzą spod piór francuskich autorów i oba do spraw francuskich się odnoszą, praca P. Matthieu została zaś po francusku wydana, co z kolei da się - być może - w jakiejś mierze objaśnić nie tylko bliskością francuskiej granicy, ale i wspomnianymi na wstępie planami francuskich wojaży, które przedsięwziąć mieli śląscy arystokraci i do których należało się wcześniej intelektualnie przygotowywać, przy okazji podnosząc swoje kompetencje językowe.

Spod pióra francuskiego autora pochodzi jeszcze jedna książka, o której wiadomo, że znajdowała się w posiadaniu J.J. Cygana. Mowa tu o obszernym dziele Commentariorum iuris ciuilis libri $X$. autorstwa Franciscusa Connanusa, wydanym w Paryżu w 1558 r., które J.J. Cygan 10 XI 1621 r. ofiarował założonej ledwie sześć lat wcześniej bibliotece Akademii w Groningen, gdzie też jest ono przechowywane do dziś dnia ${ }^{53}$. Jak sugerować może XVI-wieczna jeszcze oprawa, pochodząca - jak wynika z analiz przeprowadzonych przez E.R. Kluyvera - z miejscowego warsztatu, wskazaną wyżej książkę pan ze Słupska nabyć musiał prawdopodobnie już w Groningen. Powstała w 1615 r. biblioteka była wówczas jeszcze bardzo niewielka, a do jej wzbogacania przyczyniały się w dużej mierze dary wysoko postawionych osób. O ich zawartości

wa”, opis na podstawie listów Wacława Sobocińskiego do autora z 10 VI 1994 i 10 VII 1996. Kustoszowi Biblioteki Uniwersyteckiej we Wrocławiu Wacławowi Sobocińskiemu (1942-2019) winienem wdzięczność za wszechstronne, niezwykle owocne i inspirujące wsparcie przez wiele lat udzielane moim wrocławskim kwerendom.

53 Opis katalogowy zachowanego w Groningen egzemplarza zob.: [online] https://rug. on.worldcat.org/oclc/66289671 [dostęp 11.02.2021]. 
decydować mieli zaś ofiarodawcy wespół z bibliotekarzami ${ }^{54}$. Czy było tak również w przypadku daru J.J. Cygana, nie wiadomo. Niemniej informacja o śląskim ofiarodawcy została $\mathrm{w}$ katalogu biblioteki skrzętnie zapisana. Co ciekawe, poza adnotacją identyfikującą J.J. Cygana jako ofiarodawcę pracy Connanusa, nie są tymczasem znane żadne inne przekazy na temat pobytu frysztackiego pana w Groningen.

I to w zasadzie już wszystkie informacje, jakie udało się do tej pory zebrać na temat druków i rękopisów będących własnością J.J. Cygana. Jeśli jakaś większa kolekcja książek znajdowała się w jego posiadaniu i przechowywana była na dworze w Dobrosławicach w czasie, kiedy przebywał tam D. Czepko, właściciel mógł ją zabrać z sobą, przenosząc się po ślubie z M. Kochcicką do dworu w Zakrzowie. Niestety o historii tego miejsca po śmierci Jana Jerzego, podobnie zresztą jak i o losach właścicielki, wdowy po panu ze Słupska, o której zachowały się informacje, iż zaliczając się do grona wykształconych kobiet, sama miała przejawiać intelektualne aspiracje i utrzymywać kontakty z ówczesnymi uczonymi, niczego tymczasem nie wiadomo ${ }^{55}$.

Przetrwał za to inwentarz majątku w Dobrosławicach sporządzony 12 II 1654 r., dwa dni po śmierci W.F. Cygana ${ }^{56}$. Zawiera on specyfikację majątku ruchomego odnalezionego w miejscowym dworze. Mimo olbrzymiego zadłużenia, które ciążyło na dobrach Cyganów, a którego wysokość - jak ujawniło postępowanie egzekucyjne - niemal dwunastokrotnie przerosła wartość tegoż majątku, w izbach dobrosławickiego dworu odnaleziono - jak odnotował to już Josef Zukal - sporo kosztownego, zdobionego srebrem i złotem odzienia. Uwagę zwracała także obecność wielu skrzyń, szkatuł, szkatułek, kufrów, sakw podróżnych, a ponadto stołów do pisania czy sekretarzyków oraz pulpitów, czy raczej tablic do pisania („Schreibtaffel”), z których co najmniej jedna obita była srebrem i ozdobiona herbem. W wielu z tych sprzętów kryły się różnego typu

54 Catalogus librorum bibliothecae illustris ac almae universitatis illustrium \& praepotentium Groningae et Omlandiae ordinum: Secundum seriem litterarum digestus. Novo supplemento et notitia librorum manu scriptorum auctus, Groningae 1722, s. ++v., [online] https://books.google.pl/ books?id $=\mathrm{xPWg} 7 \mathrm{MDZYnsC} \& \mathrm{pg}=\mathrm{PP} 8 \& \mathrm{dq}=\% 22$ Catalogus + librorum + bibliothecae + illustris $+\mathrm{ac}+\mathrm{al}-$ mae+universitatis $\% 22+$ Czigan\&hl $=$ pl\&sa $=X \& v e d=2$ ahUKEwiS0NSWipHtAhWPy6QKHajWAIcQ6AEwAHoECAAQAg\#v=onepage $\& \mathrm{q}=$ Czigan $\& \mathrm{f}=$ false [dostęp 11.02.2021]; E.R. Kluyver, Stempels van NP op Groningsche banden, „Het Boek”, Jg. 11: 1922, s. 2-3; G.C. Huisman, The University Library of Groningen. Four hundred years of history in four buildings, forty collections and infinite pictures, Groningen 2002, s. 42-48, [online] https://www.rug.n1/library/_shared/pdf/400years-university-library.pdf [dostęp 11.02.2021].

55 „Es ist zu mercken, daß diese Gemahlin des Hn v. Czigan mit unter die Gelehrten Frauen Zimmer zu rechnen. Dieweil sie ihr Gemahl glücklich INFORMiret, daß sie mit gelehrten Leuten Briefe wechseln und mit ihnen lateinisch DE REBUS ERUDITIS DISCURRIren können“, cyt. za: D. Czepko, Sämtliche Werke..., Bd. 3, s. 43.

56 ZAO, zespół: Hejtmanský úřad knížectví opavsko-krnovského, stara sygn. 122, nr inw. $310, \mathrm{bp}$ 
dokumenty czy pisma, ale także kalendarze, których w sumie naliczyć można było w Dobrosławicach 30, przy czym w jednym przypadku chodziło o „Calendarz a przi niem schreibtaffel”. Jeszcze więcej znajdowało się tu map i grafik („,Koperstychu”), których w jednej z izb naliczono aż 88. Dziewięć kolejnych odnaleziono we fraucymerze, gdzie znajdować się miały także cztery „Obrazy na Platnie Koperstychu a w ramich”. Co jednak z naszej perspektywy wydaje się najbardziej interesujące, w kilku miejscach natrafiono także na książki. Pomijając dwie „Knizky wazane a nepsane”, w inwentarzu wymieniono: „Modlitby Male Nemeczke”, dwie „Knizeczky Maliczke Latinske”, a przede wszystkim „na Gednym Stole Wsseligakych Knich Malych y Welkych 41 Kusuw” oraz - chyba w obrębie fraucymeru - zieloną skrzynię, a w niej „wsseligake Knihy a Coperstychy", których liczby niestety nie podano. Co ciekawe, dokumentacja egzekucyjna dotycząca majątku pozostawionego przez ostatniego z braci Cyganów zawiera także korespondencję z baronem Emerykiem Sunegkiem, właścicielem bielskiego państwa stanowego, pozostającym chyba w dość zażyłych relacjach ze zmarlym W.F. Cyganem, który oddał mu na przechowanie nieco książek (,wenige Bücher”) oraz szpargałów („Scarteten”), pozostawiając jakoby bielskiemu panu swobodę decydowania o losie tegoż zbiorku. Wobec gorliwości, z jaką poszukiwano dóbr, które zaspokoić mogłyby żądania wierzycieli, także ten - bliżej nieokreślony - zbiór książek baron Sunegk zdecydował się pozostawić do wglądu zgłaszającym stosowne roszczenia ${ }^{57}$.

Fakt, iż sporządzony w Dobrosławicach inwentarz nie zawiera precyzyjnych danych dotyczących zawartości przechowywanego tam zbioru książek ani nawet ich dokładnej liczby, bardzo rozczarowuje, ponieważ - jak wskazują choćby niedawne publikacje odnoszące się do Śląska Cieszyńskiego inwentarze pośmiertne szlachty śląskiej, $\mathrm{w}$ wielu przypadkach specyfikujące tytuły przechowywanych w danym dworze druków i rękopisów, są trudnym do przecenienia źródłem informacji na temat szlacheckich księgozbiorów ${ }^{58}$. Jak zaświadcza przykład inwentarza sporządzonego po śmierci barona Jerzego Sobka z Kornic, niekiedy stanowić mogą wręcz jedyne źródło pozwalające ujawnić istnienie nieznanej wcześniej biblioteki, której zawartość, a przede wszystkim objętość, w tym przypadku przekraczająca liczbę 670 tomów, lokują ją pośród najbardziej interesujących, a zarazem największych podówczas szlacheckich kolekcji książek nie tylko na Śląsku, ale i w tej części Europy $^{59}$.

57 Tamże.

58 Na temat szlacheckich pośmiertnych inwentarzy z terenu Górnego Śląska i ich znaczenia badawczego zob. szerzej: W. Gojniczek, Dwór Jana Tschammera $w$ Dolnym Ustroniu w świetle inwentarza pośmiertnego z 1689 roku, „Rocznik Muzeum Górnośląski Park Etnograficzny w Chorzowie”, 2016, s. 10-13, tam również dalsza literatura, w tym dotychczasowe edycje inwentarzy.

59 Pochodzący z 1657 r. Wypis z Inwentarze kterehoz Datum na Landeku w Sobotu po Swatem 
Jakkolwiek inwentarz jest nieprecyzyjny, błędem byłoby zlekceważenie zawartych w nim danych. Wszak potwierdzają one obecność książek na dworze Cyganów, co więcej, zdają się sugerować, że książki te znajdowały się w użyciu. Wskazuje na to ich obecność w kilku miejscach dworu, w tym na jednym ze stołów, gdzie były łatwo dostępne, zaś korespondencja barona Sunegka dowodzi przy tym dodatkowo, że znajdujące się w posiadaniu ostatniego z Cyganów książki ten z jakichś względów udostępnił także na zewnątrz, co świadczyć może, iż dla mieszkańców dworu w Dobrosławicach nie były one tylko niezauważanym na co dzień elementem wyposażenia, ale stanowiły istotny i przyciągający uwagę przedmiot zainteresowania i towarzyskich kontaktów. Na istnienie ponadstandardowych preferencji kulturalnych wskazuje także obecność na dworze Cyganów pokaźnej liczby „Coperstychów”, tabulatury na lutnię ${ }^{60}$, a przede wszystkim bogate wyposażenie piśmiennicze, liczne stoliki oraz tablice czy pulpity do pisania itp. Ich obecność w różnych miejscach dworu jest bardziej jeszcze uderzająca, jeśli zestawi się ją z jedną jedyną sztuką broni („,kord postrzibrzeny”), jaką inwentaryzujący wyposażenie zdołali znaleźć w Dobrosławicach.

Szczupłość informacji, jakie udało się do tej pory zgromadzić na temat książek znajdujących się w posiadaniu barona J.J. Cygana nie pozwala orzec, w jakiej mierze poetyckie zestawienie jego postaci z samym Lukullusem, jednym z największych starożytnych kolekcjonerów i bibliofilów, znajdowało odzwierciedlenie w rzeczywistości. Nie ulega jednak wątpliwości, że książki od wczesnej młodości przyciągały uwagę pana ze Słupska, znajdowały się w jego otoczeniu i były przez niego studiowane, stanowiąc zarazem przedmiot kontaktów środowiskowych. Analiza biografii barona Cygana i jego aktywności dostarczyć może

Bartolomegi Letha 1649 teykagiczy se wssech pozustalych knich po Neb. Urozenym Panu Panu Girzyku Sobku Swobodnym Panu z Kornitz on en czaß na Welke Rudiczy, Landeku a Ropiczy od Narzizenych Panuw Commissarzuw G.K. Mti. sepsanych a poznamenanych ... zachował się w: Książnica Cieszyńska, Kolekcja rękopisów biblioteki ks. Leopolda J. Szersznika, sygn. DD IX 43; prawdopodobnie w posiadaniu ks. Leopolda Jana Szersznika znajdował się także oryginał inwentarza, który zapewne za sprawą Albina Heinricha trafił jednak do Brna i obecnie przechowywany jest w: Moravský zemský archiv v Brně, zespół: G 11: Sbírka rukopisů Františkova muzea v Brně (9.) 14.-19. století, kolekcja pt.: „Urkunden u. historischen- topographisch. Notaten Schlesien betreffend gesammelt v. A. Heinrich" (č. inv. 387, sygn. 379), K. Szelong, Kolekcja rękopisów biblioteki ks. Leopolda Jana Szersznika i jej obraz w XIX-wiecznym repertorium Albina Heinricha. Wprowadzenie do edycji, [w:] A. Heinrich, Repertorium codicum manuscriptorum in cesareo-regia Bibliotheca Scherschnickiana Teschinii, wyd. U. Wieczorek, Wrocław 2004, s. 4-25; por. też: Tenże, Podróże edukacyjne..., s. 76-77; J. Spyra, Historiografia a tożsamość regionalna w czasach nowożytnych na przykładzie Śląska Cieszyńskiego w okresie od XVI do początku XX wieku, Częstochowa 2015, s. 91-93; autor niniejszego artykułu przygotowuje krytyczną edycję inwentarza Jerzego Sobka.

60 Mogła to być pozostałość po Heinrichu Kolbie, muzyku, który przez siedem lat, zarówno w kraju, jak i za granicą umilał braciom Cyganom czas grą na lutni, a po śmierci Wacława Fryderyka wystąpił z roszczeniem do pozostawionego przez niego majątku, ponieważ panowie ze Słupska nie wypłacili mu jakoby ani jednego talara z zakontraktowanego honorarium wynoszącego 100 talarów rocznie, J. Zukal, Paméti opavské..., s. 222, 227. 
zatem interesujących przesłanek do refleksji nad źródłami inspiracji i przebiegiem procesu formowania się czytelniczych zainteresowań i aspiracji, czy nawet szerzej - kultury książki na dworach nowożytnej szlachty na Górnym Śląsku.

Pod jednym względem książkowa spuścizna J.J. Cygana zasługuje na szczególną uwagę. Jako jeden z nielicznych górnośląskich szlachciców pozostawił on po sobie superekslibris, który - w świetle aktualnego stanu wiedzy - uznać można zarazem za drugi tego typu znak książkowy osoby związanej z księstwem cieszyńskim. Posiadaniem pierwszego mógł się poszczycić Wacław Grodziecki, znany kartograf i brat biskupa ołomunieckiego, który wywodził się ze starej cieszyńskiej rodziny Grodzieckich z Grodźca ${ }^{61}$. Obu właścicieli superekslibrisów łączy fakt, że na obszarze Śląska Cieszyńskiego spędzili tylko swoje dzieciństwo.

\section{Bibliografia}

Źródła rękopiśmienne

Biblioteka Uniwersytecka we Wrocławiu, Henel, M., Silesia Togata (rkps.), sygn. R 570 (mf 8385).

Książnica Cieszyńska, Kolekcja rękopisów biblioteki ks. Leopolda J. Szersznika, Wypis z Inwentarze kterehoz Datum na Landeku w Sobotu po Swatem Bartolomegi Letha 1649 teykagiczy se wssech pozustalych knich po Neb. Urozenym Panu Panu Girzyku Sobku Swobodnym Panu z Kornitz on en czaß na Welke Rudiczy, Landeku a Ropiczy od Narzizenych Panuw Commissarzuw G. K. Mti. sepsanych a poznamenanych ..., sygn. DD IX 43.

Moravský zemský archiv v Brně, zespół: G 11: Sbírka rukopisů Františkova muzea v Brně (9.) 14.-19. století.

Österreichisches Staatsarchiv, Hofadelsakt Czigan von Slupska 1611, sygn. AT-OeStA/ AVA Adel HAA AR 172.7.

Zemský archiv v Opavě, zespoły: Hejtmanský úřad knížectví opavsko-krnovského, Slezský stavovský archiv, Josef Zukal.

Edycje źródłowe, herbarze, metryki uniwersyteckie Album Studiosorum Academiae Lugduno Batavae MDLXXV-MDCCCLXXV accedunt nomina curatorum et professorum per aedem secula, ed. W.N. Du Rieu, Hagae Comitum 1875.

Czepko D., Sämtliche Werke, unter Mitarbeit von U. Seelbach hrsg. von H.-G. Roloff und Marian Szyrocki, 6 Bde, Berlin und New York 1980-1998.

61 M. Cubrzyńska-Leonarczyk, Polskie superekslibrisy XVI-XVIII wieku w zbiorach Biblioteki Uniwersyteckiej w Warszawie. Centuria Druga, Warszawa 2001, s. 158-159; J. Polak, T. Wojton, Wacław Grodecki stawny kartograf, Grodziec, Bielsko-Biała 1991, 13 s.; K. Szelong, Podróże edukacyjne..., s. 71-72. 
Frank, K.F. von, Standeserhebungen und Gnadenakte für das Deutsche Reich und die österreichischen Erblande bis 1806 mit einigen Nachträgen zum „Alt-Österreichischen Adels-Lexikon“ 1823-1918, Bd. 2: F-J, Schloss Senftenegg 1967.

Graesse J.G.Th., Geschlechts-, Namen- und Wappensagen des Adels Deutscher Nation, Dresden 1876.

Die Matrikel der Universität Altdorf, hrsg. E. v. Steimeyer, Bd. 2, Würzburg 1912.

Neues allgemeines Deutsches Adels-Lexicon, hrsg. E.H. Kneschke, Bd. 2, Leipzig 1860.

Paprocki B., Herby rycerstwa polskiego, Kraków 1858.

Pilnáček J., Rody starého Slezska, Vyd. 2, Brno 1991-1998.

Scherffer von Scherfferstein W., Geist- und weltlicher Gedichte. Erster Teil, Brieg 1652, hrsg. E. Pietrzak, Tübingen 1997.

Szymański J., Herbarz średniowiecznego rycerstwa polskiego, Warszawa 1993.

Stare druki

Aleuthner T., Melos Epithalamium. Nuptiarum festivitati, Quam Generis Antiqui, Virtutis variae ... Vir Nobilissimus Et Magnificus. Dn. Wenceslaus Scheliha De Rzuchaw, In Wahnowitz/ Sawerwitz/ Sackraw/ \& Huhndorff/ \&c. Sponsus, Cum Natalium ... Feminarum ornamentis illustribus conspicua adolescentula Heroina Dn: Marianna Kochticia, Illustris Ac Generosi Domini, Dn: Andrea Kochtizky ... Filia Charis: Sponsa : Coselae Silesior. Ad 8. Eid. Quinctil. ... 1624. Solemn. instituebat Adcantatum nuncupatum, Nissae 1624.

Anther N., Heerman, G., Zwo Christliche Leich Predigten Uber dem Seeligen Abschiede Weyland Des Wolgebornen Jüngen Herrens/ Herrn Christoff Czigans Von Slußka auff Freystadt/ u. Welcher am II Octob. An. 1606. zum Brieg auß der Fürstlichen irdischen/ in die Himlische Schule versetzet und 2. Novembr. Anni ejusdem hernach zur Freystadt inn grosser Anschnlicher versammlung der Betrübten Blutsfreundschafft und anderer rittermessigen Personen inn seine Erbgrufft ist gesamlet worden. Die Erste. Bey Abführung seines verblichenen Cörpers auß der Füstl: Stadt Brieg/nach der Freystadt seiner Sepultur/gehalten zum Brieg 22 Octob. vorm Oppelischen Thore Durch Nicolaum Antherum Fürstlichen Briegischen Hoffprediger/ und gemeltes Fürstenthumbs General Superintendenten. Die Andere. Bey der Volckreichen bestattung und beysetzung den 2. Novemb. in der Pfarkirchen zur Freystadt/Gethan durch Georgium Heerman. B S. Pastorem und Inspectorem der Kirchen und schulen daselbst, [Brzeg 1606?].

Ara honoris viro nobilissimo et eminentissimo Jacobo Schickfusio Svebvsiensi Silesio, novo juris utriusq; doctori, Gymnasii Bregensis Rectori, Institutionum Imperial. Professori, bene merito Praeceptor posita a Baronibus illustre Bregeum frequwntantibus V. Novembr. Stilo. N. Anno M.DC.XII., Bregae 1612.

Barlaeus C., Poemata, tum quae antehac edita fuerunt: tum quae jam singulari libro nova in lucem prodierunt, T. 1, Lugduni Batavorum 1630. 
Bernegger M., Collegivm Politicum Lipsianum In Inclytâ Argentoratensi Academiâ ab Illustribus, Generosis, Nobilissimis Atqve Florentissimis juvenibus quibusdam institutum, Moderante M. Matthia Berneggero, Argentorati 1617 .

Bernegger M., Cygan J.J., Iusti Lipsii Politicorum Liber I. De duobus civilis vitae directoribus, Virtute \& Prudentia, cu[m] annexis / a Joanne Georgio Czigan, L.B. de Slupska \&c: In aphorismos redactus, \& in Illustri Argentoratensium Academia, Propositus ad examinandum, Praeside Matthia Berneggero, Historiarum In eadem Prof. Ordinario, Argentorati 1616.

Bitsch C., A. Scholl, De Codicillis Et Clausula Codicillari, Disputatio III. Tractans de causis, materiali \& formali / De qua ... In alma Academia patria, Praeside Casparo Bitschio I.U.D. ... Publice respondebit Die Martii Andreas Schollius Argentoratensis, Argentorati 1617.

Bruck Angermundt J., Decades duae anagrammatum et emblematum ex nomine Illustris, Generosi, et Magnifici Domini, D. Andeae Kochticzky, Argentorati 1615.

Bruck Angermundt J., Emblemata Moralia \& Bellica (Les Emblemes Moraulx Et Militaires), Argentorati 1615-1616.

Bruck Angermundt J., Emblemata Politica. Quibus ea, quae ad principatum spectant, breviter demonstrantur, singuloru[m] vero explicatio fusius proponitur, Argentine 1618.

Bruck Angermundt J., Princeps Plinianus. Sive Aphorismi Politici ex C. Plini Secundi Panegyrico Ad Traianum Tetrastichis redditi. Quibus Breves Dissertationes accesserunt, Argentinae 1616 (nast. wyd. 1617).

Catalogus librorum bibliothecae illustris ac almae universitatis illustrium \& praepotentium Groningae et Omlandiae ordinum: Secundum seriem litterarum digestus. Novo supplemento et notitia librorum manu scriptorum auctus, Groningae 1722 [online] https://books.google.pl/books?id=xPWg7MDZYnsC\&pg=PP8\&dq=\%22Catalogu$\mathrm{s}+$ librorum+bibliothecae+illustris $+\mathrm{ac}+$ almae + universitatis $\% 22+\mathrm{Czigan} \& \mathrm{hl}=\mathrm{pl} \&$ $\mathrm{sa}=$ X\&ved=2ahUKEwiS0NSWipHtAhWPy6QKHajWAIcQ6AEwAHoECAAQA$\mathrm{g} \# \mathrm{v}=$ onepage $\& \mathrm{q}=$ Czigan $\& \mathrm{f}=$ false [dostęp 11.02.2021]

Crusius J.P., Obrecht, J.T., Daphnis Seu Actus Caesareus Sacratißima Sacratißimae Caesareae Maiestatis Authoritate A Iohanne Thoma Obrechto Iureconsulto Argentoratense ... in Actoasi nova celebratus: / Quo Johanni Paulo Crusio Argentoratensi Liberalium Artium Magistro ... Antiquissimum illud, dignissimum, \& nunquam emoriturum Poetarum Praemium Corona Laurea ..., Argentorati 1616.

Czepko D., Auff Deß Wolgebohrnen Herren Herren Hans Georg Czigan/ Freyherrn von Schlupska/Herrn auff Freystadt/Dobroslawitz und Sacraco/in Gott seeligen Abschied : So geschehen den 16. Jenner deß 1640. Jahres, Breßlaw 1640.

Fischer F., In obitum Illustris Heroinae Barbarae Dorotheae Cziganianae, natae L. Baronissae de Stupska, Freistadt et Dobroslawiz, Quae A. C. M DC L. Mens. Septemb. d. 27. Fatali peractae Mortalitatis termino, Terrae magnae nimirum Marti, Exuvias; Deo autem Spiritum, reddens, pie, placide, ac beate Dobroslawicii obdormivit, [Wrocław 1650]. 
Gauhe J.F., Des Heil. Röm. Reichs Genealogisch-Historisches Adels-Lexicon, Darinnen die älteste und ansehnlichste adeliche, freyherrliche und gräfliche Familien nach ihrem Alterthum, Ursprunge, Vertheilungen in unterschiedene Häuser [et]c. nebst den Leben derer daraus entsprossenen berühmtesten Personen, insonderheit Staats-Minister ... mit bewährten Zeugnissen vorgestellet werden ..., Leipzig 1740.

Götzen G.H., Diptycha Exulum, Oder Exulanten-Register, Darinnen die Nahmen derer Beständigen Lutheraner angeschrieben stehen, Welche Um der Lehre des Evangelii willen, zwar verfolget, und ins Elend vertrieben worden, doch gleichwohl aber Göttl. Beschirmung und Seegen mit denen Ihrigen wieder gefunden haben ... Nebst Einer Exulanten-Predigt über Matth. XIX. v. 29., Altenburg 1714.

Henel M., Silesiographiae Henelianae renovatae pars altera [Cap. VIII., De statu hominum sive Generibus et ordinibus, quibus Silesiarum incolae inter se distincti], Wratislaviae et Lipsiae 1704.

Lucae F., Schlesiens curieuse Denckwürdigkeiten/oder vollkommene Chronica von Oberund Nieder-Schlesien/: welche in Sieben Haupt-Theilen vorstellet Alle Fürstenthümer und Herrschafften/ mit ihren ... Landes-Fürsten ... Geschlechtern ... Wappen ... / Ausgefertiget von Friderico Lucae, Franckfurt am Mäyn 1689.

Magirus W., Desiderium Terrae Viventium, Hertzliches verlangen/ nach dem Lande der Lebendigen. Das ist Eine Christliche Leichpredigt/ auß dem 12. und 13. vers des Sieben und Zwantzigsten Psalms Davids : Gehalten/ Uber dem Seligen abschiede/ und Christlicher Leichbegängnis/ Des Weyland Ehrwürdigen/ Achtbarn und Wolgelarten Herrn M. Adami Büthneri, Poetae. L.C. trewfleißigen und verdienten Pastoris, der Kirchen Christi/ in der Dantzker Vestung Weisselmünde. Welcher Anno Christi 1643. den 5. Sontag nach Trinitatis zwischen 9. und 10. Uhren des Morgens unter wehrendem Gottesdienste/ in wahrem glauben/ und Standhaffter Bekentnis Jesu Christi sanfft und stille/ bey guter vernunfft sein leben beschlossen/ und den folgenden Mittwoch/ war der 8. Julii mit Christlichen Ceremonien zur Erden bestattet, Dantzig 1644.

Meier J., Pandectarvm Vniversi Ivris Civilis, Sive Collegii Ivridici Argentoratensis. Omne Jus Pandectarum, Quodque Eidem Ex Codic. Instit. Novell. Justinianeis respondet, una perpetuaque causarum methodo dispositum: cum supplemento Juris tum Canonici, tum Novissimi ex Imperial. Constit. \& forensibus observationibus, exhibentis: Tomus Posterior : In Academia Argentoratensi A Doctissimis Iuris Candidatis Ac studiosis perfectus \& recensitus cura Iusti Meieri Noviomagensis I.U.D. ..., Argentorati 1617.

Monardes N., Ein nützlich und lustig Gespräche/ Von Stahl und Eisen : Darinnen dieser Metallen Würdigkeit und ArtzneyTugenden angezeiget werden / Erstlich in Spanischer Sprache geschrieben/von ... Nicolao Monardo, und vor wenig Jahren in die Lateinische gebracht/ durch ... Carolum Clusium, Jetzo aber ... in unsere Deutsche Sprache versetzt ... durch Jeremiam Gesnerum ... Sampt einem andern Tractätlin/Von dem Schnee und Eyß ..., Leipzig, Breslaw 1615.

Murovius D., Bivium Herculis ad Ilustres et Generosos L.B. Jan Bernhardum Malczan L.B. a Wartemberg et Penczelin in Milicz ..., Dn. Jan Georgium Czigan L.B. a Slupska 
in Freistad et Drobroslawicz ..., Joachimum Kochticzki L.B. a et in Kochticz et Lubleniecz ..., Andream Kochticzki, L.B. a Kochticze et Lubleniecz in Kossentin et Turnawa ... studiorum gratia Argentoratum profecturos, deinde Galliam et Italiam perlustraturos ephoro nobili et cl. viro Dn. Jacobo a Bruck cogn. Angermund, Breslae 1614.

Nuptiis viri clarissimi et doctissimi ... M. Joannis Hartmanni, Gymnasii Svidniciensis Con-Rectoris ... sponsi et ... Susannae Langiae ... Wolfgangi Langii ... filiae ... ad diem 26. Augusti Anno 1613. celebrandis, Lignici [post 26 VIII 1613].

Orationes duae, qvarum prior de literarum encomio illarum utilitate et praestantia a Johanne Bernhardo Malczan L.B. a Wartenberg et Penczelin in Milicz etc., altera metricis pedibus contexta ab Andrea Kochticzki, L.B. a Kochticz et Lublenietz in Kossenczin et Turnawa, annum aetatis 15 agente in arce Kossentina cum Musis ibi valedicerent 7 id. Octob: hora 9. matut: an 1614 habitae Illustribus, Magnificis, ac Generosis, Prudentia Ac Pietate praestantibus Dominis, Dn: Joachimo Malczan L.B. a Wartenberg ... et Dn. Andreae Kochticzki L.B. a Kochticz et Lubleniecz ... dominis parentibus debitae observantiae et gratitudinis ergo dicatae, Breslae 1614.

Othonia J., Johannae Othoniae, Foeminae Flandriae. Viri Clarissimi, Domini Guilielmi Mayarti, In Provinciali consilio Flandriae quondam Advocati consultissimi, Carminum Diversorum Libri Duo, Argentorati 1616.

Paprocki B., Zrdcadlo slawneho Margkrabstwij Morawskeho w kteremż geden każdy staw, dawnost, wzactnost y powinnost swau vhleda / kratce sebrane a wydane roku 1593 skrze Bartholoměge Paprockeho..., Olomvtii 1593.

Ramsler R., Blumen des fürstlichen Collegii zu Tübingen : das ist ... Verzeichnus aller ... Personen, die in diesem Collegio geflanzet ... durch angeborne Wappen unterschieden werden, Tubinga 1627.

Scherffer W., Leichgesänge und Grabschrifften, Brig 1646.

Sinapius J., Des schlesischen Adels anderer Theil, oder Fortsetzung Schlesischer Curiositäten: darinnen die gräflichen, freyherrlichen und adelischen Geschlechter so wohl Schlesischer Extraction, als auch die aus andern Königreichen und Ländern in Schlesien kommen, und entweder darinnen noch floriren ..., Leipzig und Breßlau 1728.

Tacyt C. Cornelii Taciti De Vita Julii Agricolae Liber, exp. a M. Berneggero, Argentorati 1617. Tilesius N., PfingstPredigten : In welchen aus dem Alten und Newen Testament/ Lehrhafftige und Trostreiche Sprüche/ auff dasselbige gnadenreiche Fest gerichtet/ gehandelt werden / Gehalten In unterschiedlichen Jahren ... Durch M. Nathanaëlem Tilesium ..., Breslau, Leipzig 1611.

Weinschenk J.G., Historische Nachricht von der Stiftung und den Schicksalen des königlichen Gymnasii Illustris zu Brieg wie auch von dessen Rectoribus und Professoribus, bey den Andenken der vor zweyhundert Jahren geschehenen Grundlegung desselben abgefasset..., Brieg 1764. 
Opracowania

Bedyński T., Gdański geograf Filip Kluwer (1580-1622) twórca granic wspótczesnej Europy, Warszawa 2002.

Cejpek J., Hlaváček, I., Kneidl, P., Dějiny knihoven a knihovnictví v českých zemích a vybrané kapitoly z obecných dějin, Praha 1996.

Cubrzyńska-Leonarczyk M., Polskie superekslibrisy XVI-XVIII wieku w zbiorach Biblioteki Uniwersyteckiej w Warszawie. Centuria Druga, Warszawa 2001.

Fuchs P., Clüver Philipp, [w:] Neue Deutsche Biographie, 3 (1957), s. 295-296.

Fukala R., Ozvěny chebských událostí ve Slezsku, „Historica. Revue pro historii a př́buzné vědy", 1/1, 2010, s. 3-10.

Fukala R., Stavovská politika na Opavsku v letech 1490-1631, Opava 2004.

Gojniczek W., Dwór Jana Tschammera w Dolnym Ustroniu w świetle inwentarza pośmiertnego z 1689 roku, „Rocznik Muzeum Górnośląski Park Etnograficzny w Chorzowie", 2016, s. 9-33.

Haertel E., Andreas Freiherr von Kochtitzky ein Mäzen Oberschlesiens um die Zeit des Dreißigjährigen Krieges, T. 1-2, „Der Oberschlesier”, 1936, H. 9, s. 487-493, H. 11, s. 578-584.

Haertel E., Der Kochtizkykreis. Ein Kulturbild aus Oberschlesien vom Beginn des 17. Jahrhunderts, „Schlesische Geschichtsblätter”, 1941, 3/4, s. 69-75.

Haertel E., Jacob von Bruck-Angermundt, ein vergessener Dichter und großer Patriot Schlesiens, „Zeitschrift des Vereins für Geschichte Schlesiens”, 1941, s. 130-137.

Holý M., Zrození renesančního kavalíra. Výchova a vzdělávání šlechty z českých zemí na prahu novověku (1500-1620), Praha 2010.

Horwat J., Jedynak Z., Kiereś Z., Genealogia kilku rodzin szlacheckich z ziemi gliwickiej, toszeckiej i bytomskiej (cz. 3), „Zeszyty Gliwickie”, 31, Gliwice 2003, s. 21-68.

Hultsch G., Daniel Czepko von Reigersfeld 1605-1660, „Jahrbuch für Schlesische Kirchengeschichte“, 1960, s. 91-113.

Igálffy-Igály L., Die Freiherren Kochticky von Kochtitz und Lublinitz, „ «Adler» Zeitschrift für Genealogie und Heraldik", 1979/1981, s. 123-143.

Igálffy-Igály L., Die Kiczka-Karwinsky. Eine Studie über die Herkunft der Freiherrn Karwinsky von Karwin und Czigan von Slupsk und aller anderen Familien desselben Wappen (maszynopis powielony), Wien 1969.

Ingen F. van, Daniel von Czepkos Consolatio ad Baronissam Cziganeam. Tröstung, Rhetorik, Psychologie, [w:] Die oberschlesische Literaturlandschaft im 17. Jahrhundert, hrsg. G. Kosellek, Bielefeld 2001, Tagungsreihe der Stiftung Haus Oberschlesien, Bd. 11, s. 197-220.

Iwanek W., Renesansowa plastyka nagrobna na Ślasku Cieszyńskim, „Cieszyński Rocznik Muzealny", 1972, t. 3, s. 63-82.

Johann Georg Czigan (Freiherr), Wikipedia, [online] https://de.wikipedia.org/wiki/Johann_Georg_Czigan_(Freiherr)\#cite_ref-5 [dostęp 02.02.2021].

Kluyver E.R., Stempels van NP op Groningsche banden, ,Het Boek”, 1922, s. 1-8. 
Huisman G.C., The University Library of Groningen. Four hundred years of history in four buildings, forty collections and infinite pictures, Groningen 2002, s. 42-48, [online] https://www.rug.nl/library/_shared/pdf/400years-university-library.pdf [dostęp 11.02.2021].

Kolár̆, M., Cikánové ze Slupska, [w:] Ottưv slovník naučný, D. 5, Praha 1892, s. 367-368.

Kozierowski S., Obce rycerstwo w Wielkopolsce, Poznań 1929.

Makowski M., Spyra J., Szelong K., Zbiory i Fundacja Szersznika po 1814 r., [w:] 190 lat założenia Muzeum i Biblioteki Leopolda Jana Szersznika 1802-1992, pod red. J. Spyry, Cieszyn 1993, s. 81-90.

Meier A., Daniel Czepko als geistlicher Dichter, Bonn 1975, Studien zur Germanistik, Anglistik und Komparatistik, Bd. 33.

Milch W., Daniel Czepko. Persönlichkeit und Leistung, Breslau 1934, Einzelschriften zur Schlesischen Geschichte, Bd. 12.

Müller K., Heraldické památky Těšinska, Český Těšín 2012, Studie o Těšínsku, 20.

Oszczanowski P., Przygoda pewnych emblematów, czyli rzecz o destrukcji wzorca, „Dzieła i Interpretacje", 1996, s. 171-179.

Pawelec M., Büthner Adam, [w:] Stownik pisarzy śląskich, pod red. J. Lyszczyny i D. Rotta, T. 3, Katowice 2010, s. 19-21.

Pawłowiczowa M., Szymon Pistorius w kręgu Andrzeja Kochcickiego, [w:] Prace Historycznoliterackie, 12: Studia Staropolskie, pod red. J. Zaremby, Katowice 1979, s. 75-88.

Piprek J., Wacław Scherffer von Scherfferstein. Poeta śląki i polonofil XVII wieku, Opole 1961.

Polak J., Wojtoń, T., Wacław Grodecki stawny kartograf, Grodziec, Bielsko-Biała 1991.

Prasek V., Slavní někteři mužové z Těšinska, „Kalendář slezský”, 6, 1902, s. 50-54.

Schilling M., Handschrift und Druck, Anagramm und Emblem. Ein unbekanntes Emblembuch des Jakob von Bruck-Angermundt mit Stichen von Matthaeus Merian, [w:] Polyvalenz und Multifunktionalität der Emblematik, T. 2 (Mikrokosmos. Beiträge zur Literaturwissenschaft und Bedeutungsforschung, Bd. 65), hrsg. W. Harms, D. Peil, Frankfurt am Main 2002, s. 753-771.

Schilling M., Jakob von Bruck-Angermundt und seine Emblembücher, [w:] Die oberschlesische Literaturlandschaft im 17. Jahrhundert, hrsg. G. Kosellek, Bielefeld 2001, Tagungsreihe der Stiftung Haus Oberschlesien, Bd. 11, s. 135-156.

Schönwälder K.F., Geschichtliche Ortsnachrichten von Brieg und seinen Umgebungen. Einleitung. Vorstädte. Umgebung, Th. 2, Brieg 1846.

Schönwälder,K.F., Guttmann J.J., Geschichte des Königlichen Gymnasiums zu Brieg, Breslau 1869.

Seelbach U., Die Ermittlung personenbezogener Informationen für den Kommentar der Czepko-Ausgabe, [w:] Kommentierungsverfahren und Kommentarformen. Hamburger Kolloquium der Arbeitsgemeinschaft für germanistische Edition, 4. bis 7. März 1992, autor- und problembezogene Referate, hrsg. G. Martens, Tübingen 1993, s. $223-230$. 
Šipek R., Die Jauerer Schlossbibliothek Ottos des Jüngeren von Nostitz, T. 1, Frankfurt am Main 2014.

Spyra J., Historiografia a tożsamość regionalna w czasach nowożytnych na przykładzie Śląska Cieszyńskiego w okresie od XVI do początku XX wieku, Częstochowa 2015.

Stebler M., Andreas Gryphius i Daniel Czepko, [w:] Dawna kultura literacka na Ślasku. Zbiór studiów, pod red. M. Borysiak i A. Galosa, Wrocław 1994, s. 79-90.

Stebler M., Daniel Czepkos Coridon und Phyllis. Eine Analyse des Epos mit Strophenkommetar zum Ersten Buch, Wrocław 1995, Acta Universitatis Wratislaviensis, no 1752, Germanica Wratislaviensia, CXIII.

Strasser K.T., Der junge Czepko, „Münchener Archiv für Philologie des Mittelalters und Renaissance”, hrsg. F. Wilhelma, H. 3, München 1913.

Szelong K., Andreas Kochtitzki d.̈̈. - Mäzen, Politiker, Soldat, [w:] Adel in Schlesien, Bd. 1: Herrschaft - Kultur - Selbstdarstellung, hrsg. J. Harasimowicz u. M. Weber, München 2010, s. 363-392.

Szelong K., Biblioteczne zbiory Leopolda Jana Szersznika, [w:] 190 lat założenia Muzeum i Biblioteki Leopolda Jana Szersznika 1802-1992, pod red. J. Spyry, Cieszyn 1993, s. 37-52.

Szelong K., Kolekcja rękopisów biblioteki ks. Leopolda Jana Szersznika i jej obraz w XIX-wiecznym repertorium Albina Heinricha. Wprowadzenie do edycji, [w:] A. Heinrich, Repertorium codicum manuscriptorum in cesareo-regia Bibliotheca Scherschnickiana Teschinii, wyd. U. Wieczorek, Wrocław 2004, s. 7-48.

Szelong K., Podróże edukacyjne szlachty cieszyńskiej (do końca XVII wieku), [w:] Książka - biblioteka - szkoła w kulturze Śląska Cieszyńskiego. Materiały z konferencji naukowej Cieszyn 4-5 listopada 1999, pod red. J. Spyry, Cieszyn 2001, s. 59-115.

Szelong K., Proces ewidencji i opracowania bibliotecznych zbiorów ks. Leopolda Jana Szersznika. Zarys historyczny, „Roczniki Biblioteczne”, 2000, s. 87-134.

Weltzel A., Die Landesbeamten der Fürstenthümer Oppeln-Ratibor von 1532-1741, „Zeitschrift des Vereins für Geschichte und Alterthum Schlesien”, 1874, s. 19-44.

Weltzel A., Geschichte der Stadt und Festung Cosel, Cosel 1866.

Wollgast S., Zur Kasualdichtung und Kasualrede bei und um Daniel Czepko, [w:] Theorie und Praxis der Kasualdichtung in der Frühen Neuzeit, hrsg. A. Keller i in., Amsterdam, New York 2010, Chloe, 43.

Zukal J., Die Lichtensteinische Inquisition in den Fürstentümern Troppau und Jägerndorf aus Anlaß der Mansfeldischen Rebellion 1626-1627, „Zeitschrift für Geschichte und Kulturgeschichte Österreichisch-Schlesiens", 1912, H. 1/3.

Zukal J., Paměti opavské, Opava 1912.

Zukal J., Slezské konfiskace 1620-1630. Pokutovaní provinilé šlechty v Krnovsku, Opavsku a Osoblažsku po bitvě bělohorské a po vpádu Mansfeldové, V Praze 1916. 